\title{
REDUCING INGROUP BIAS IN ETHICAL CONSUMPTION: THE ROLE OF CONSTRUAL LEVELS AND SOCIAL GOODWILL
}

\author{
Diego Costa Pinto \\ NOVA Information Management School, Portugal \\ dpinto@novaims.unl.pt \\ Adilson Borges \\ NEOMA Business School, France \\ adilson.borges@neoma-bs.fr \\ Márcia Maurer Herter \\ Universidade Europeia, Portugal \\ marcia.herter@universidadeeuropeia.pt \\ Mário Boto Ferreira \\ Universidade de Lisboa, Portugal \\ mferreira@psicologia.ulisboa.pt
}

This is the Accepted Author Manuscript of the article published by Cambridge Business Ethics Quarterly:

Costa Pinto, D., Borges, A., Maurer Herter, M., \& Boto Ferreira, M. (2020). Reducing Ingroup Bias in Ethical Consumption: The Role of Construal Levels and Social Goodwill. Business Ethics Quarterly, 30(1), 31-63. https://doi.org/10.1017/beq.2019.25 


\section{Reducing Ingroup Bias in Ethical Consumption: The Role of Construal Levels and Social Goodwill}

\begin{tabular}{|c|l|}
\hline Journal: & Business Ethics Quarterly \\
\hline Manuscript ID & BEQ-QN-18-062.R4 \\
\hline Keywords: & $\begin{array}{l}\text { ethical consumption, social influence, ingroup bias, identity cues, } \\
\text { construal level theory }\end{array}$ \\
\hline Abstract: & $\begin{array}{l}\text { Business ethics research has long been interested in understanding the } \\
\text { conditions under which ethical consumption is consistent versus context- } \\
\text { dependent. Extant research suggests that many consumers fail to make } \\
\text { consistent ethical consumption decisions and tend to engage in ethical } \\
\text { decisions associated with ingroup (vs. outgroup) identity cues. To fill this } \\
\text { gap, four experiments examine how construal levels moderate the } \\
\text { influence of ingroup versus outgroup identity cues in ethical } \\
\text { consumption. The studies support the contention that when consumers } \\
\text { use concrete construal to process information, they will focus on ingroup } \\
\text { cues and make ethical consumption decisions that are aligned with } \\
\text { ingroup biases. However, when consumers use abstract construal, they } \\
\text { will act more consistently with their inner goals rather than focus on } \\
\text { ingroup and outgroup cues. Social goodwill, which indicates desires to } \\
\text { give back to society, is identified as mediating the effects. The findings } \\
\text { have important implications for ethical consumption and social influence } \\
\text { literature. }\end{array}$ \\
\hline
\end{tabular}

\section{SCHOLARONE \\ Manuscripts}




\title{
REDUCING INGROUP BIAS IN ETHICAL CONSUMPTION: \\ THE ROLE OF CONSTRUAL LEVELS AND SOCIAL GOODWILL
}

\section{Running Head: Reducing Ingroup Bias in Ethical Consumption}

\section{Diego Costa Pinto}

NOVA Information Management School, Portugal

dpinto@,novaims.unl.pt

\author{
Adilson Borges \\ NEOMA Business School, France \\ adilson.borges@neoma-bs.fr \\ Márcia Maurer Herter \\ Universidade Europeia, Portugal \\ marcia.herter@universidadeeuropeia.pt
}

\section{Mário Boto Ferreira}

Universidade de Lisboa, Portugal

mferreira@psicologia.ulisboa.pt 


\title{
REDUCING INGROUP BIAS IN ETHICAL CONSUMPTION:
}

\section{THE ROLE OF CONSTRUAL LEVELS AND SOCIAL GOODWILL}

\begin{abstract}
Business ethics research has long been interested in understanding the conditions under which ethical consumption is consistent versus context-dependent. Extant research suggests that many consumers fail to make consistent ethical consumption decisions and tend to engage in ethical decisions associated with ingroup (vs. outgroup) identity cues. To fill this gap, four experiments examine how construal levels moderate the influence of ingroup versus outgroup identity cues in ethical consumption. The studies support the contention that when consumers use concrete construal to process information, they will focus on ingroup cues and make ethical consumption decisions that are aligned with ingroup biases. However, when consumers use abstract construal, they will act more consistently with their inner goals rather than focus on ingroup and outgroup cues. Social goodwill, which indicates desires to give back to society, is identified as mediating the effects. The findings have important implications for ethical consumption and social influence literature.
\end{abstract}

Keywords: construal level theory; ethical consumption; identity cues; ingroup bias; social influence

Citation Style: Academy of Management Journal Style Guide 


\section{INTRODUCTION}

The ideas of consistency and flexibility of consumer decision-making are a major issue in ethical consumption. Consumers who are concerned about adverse environmental and societal impacts often want to adopt sustainable and pro-social behaviors by patronizing companies that focus on ethical issues such as sustainability, fair trade, and minority empowerment (Bray, Johns, \& Kilburn, 2011; Paavola, 2001; Schaefer \& Crane, 2005). Although consumers have growing awareness that they should be ethical consumers, many show an "ethical purchasing gap" in failing to make consistent ethical consumption decisions (Barbarossa \& Pelsmacker, 2016; Carrigan \& Attalla, 2001; Kidwell, Farmer, \& Hardesty, 2013; Nicholls \& Lee, 2006; Prothero, McDonagh, \& Dobscha, 2010; Zabel, 2005).

Research in business ethics has long been interested in understanding the conditions under which ethical consumption is consistent versus context-dependent (e.g., Cooper-Martin \& Holbrook, 1993; De Pelsmacker, Dreisen, \& Rayp, 2005). Opinions and recommendations that come from others, particularly ingroup members such as family, friends, colleagues, and fellow citizens, are acutely persuasive social influences (Goldstein, Cialdini, \& Griskevicius, 2008; Thorne, Massey, \& Jones, 2004; White \& Dahl, 2007). Ingroup bias (i.e., the preference of ingroups over outgroups) is an especially strong force motivating behaviors, ethics, and moral intentions and disparaging behaviors identifying outgroup individuals, such as people from other universities, companies, or countries (e.g., Brewer, 1999; Escalas \& Betman, 2005; Garcia, Bazerman, Kopelman, Tor, \& Miller, 2010; Granitz \& Ward, 2001; Tajfel \& Turner, 1979). In addition, people tend to be more outraged by corporate malfeasance that victimizes their ingroup rather than the outgroup (Antonetti \& Maklan, 2016). 
Construal level theory (CLT) (Liberman \& Trope, 1998) explains that construal levels affect how ingroup and outgroup cues influence perceptions. That is, under abstract construal, consumers focus on broad, general features and essences of issues; under concrete construal, they focus on contextual specifics (Trope, Liberman, \& Wakslak, 2007). For instance, they might abstractly construe recycling as "saving the planet" or concretely construe it as "sorting the garbage." For our studies, we merge the social influence literature with CLT to ask: does construal moderate ingroup bias to affect ethical consumption decisions?

Drawing from construal level and contextual influence research (Ledgerwood \& Callahan, 2012; Ledgerwood, Trope, \& Chaiken, 2010; Luguri \& Napier, 2013; McCrea, Weiber, \& Myers, 2012), we propose that when individuals use concrete construal to consider ethical consumption, they will focus on contextual information and align their responses with their ingroup bias. Conversely, when they use abstract construal, they will make less contextdependent evaluations and will act more consistently with inner goals, beyond ingroup bias. Furthermore, social goodwill, which indicates desires to give back to society, will mediate the impact of construal level on ethical consumption.

To test our hypotheses, we conducted four studies across recycling (Study 1), sustainable products (Study 2), fair trade (Study 3), and women empowerment (Study 4) ethical consumption domains. In Studies 1-3, we analyze how construal level moderates influences from identity cues and ingroup bias. In Study 4, we test social goodwill and several alternative mediators. Figure 1 presents our theoretical model and summarizes the research hypotheses.

Insert Figure 1 about here. 
Our research makes important contributions to the literature on social influence (e.g., Goldstein et al., 2008) and ethical consumption (e.g., Antonetti \& Maklan, 2016; Doran, 2010; Ghorbani, Liao, Çayköylü, \& Chand, 2013). First, we extend previous findings on ingroup bias and ethical consumption. Whereas past research (Escalas \& Bettman, 2005) stated that people usually prefer ingroups than outgroups, we show that abstract (vs. concrete) construal reduces ingroup bias in ethical consumption. We thus contribute to research on social influence (e.g., Goldstein et al., 2008) and ethical consumption (e.g., Ghorbani et al., 2013; Antonetti \& Maklan, 2016; Doran, 2010), showing that construal level moderates ingroup bias. Second, this research highlights a novel mechanism of social goodwill (i.e., the importance of giving back to society). Based on the previous literature on construal level and contextual influence (Ledgerwood et al., 2010), we propose that social goodwill mediates the effects of construal level and identity cues on ethical consumption. By doing so, we contribute to recent research (Chernev \& Blair, 2015) showing under which conditions that the mediation of social goodwill predicts ethical consumption.

Finally, this research has implications for practice in business ethics combining identity cues and construal levels to foster ethical consumption. For instance, managers and public policymakers could use campaigns that associate concrete construal and ingroup cues, increasing consumers' social goodwill and willingness to pay premium prices for ethical products and services. In addition, ethical consumption campaigns for broad audiences can mitigate ingroup bias effects by activating consumers' abstract construal and ensuring ethical consumption consistency, independently of ingroup or outgroup cues. Such proposed strategies can have positive impacts on society by increasing ethical consumption while positively enhancing company profits.

\section{INGROUP BIAS, IDENTITY CUES, AND ETHICAL CONSUMPTION}


Psychological research has long focused on how consumer behavior is guided by ingroup bias (e.g., Axt, Nguyen, \& Nosek, 2018; Brewer, 1999; Mullen, Brown, \& Smith, 1992; Tajfel \& Turner, 1979), which means "intended or unintended favoritism in evaluation, judgment, or behavior for one social group over another" (Axt et al., 2018, p. 337). People tend to adhere to ingroup biases to maintain positive social identities (Tajfel \& Turner, 1979). Ingroup bias has been extensively documented (Vermue, Seger, \& Sanfey, 2018), but recent research indicates that contextual cues can alter ingroup self-categorization (Fasoli, Cadinu, Carnaghi, Galdi, Guizzo, \& Tassara, 2018) and determine whether individuals think, feel, and act in alignment with ingroups (us) or outgroups (them) (Turner, Brown, \& Tajfel, 1979; Turner, Hogg, Oakes, Reicher, \& Wetherell, 1987). Context dynamically indicates ingroup/outgroup identity cues and can thus activate understandings and actions in terms of norms, values, and behaviors relevant to particular identities (Aaker \& Akutsu, 2009; Kirmani, 2009; Oyserman, 2009, 2013; Shavitt, Torelli, \& Wong, 2009). Table 1 provides a summary of the concepts including ingroup bias, identity cues, construal level, social goodwill, and ethical consumption.

Insert Table 1 about here.

Identity cues and ingroup biases are known to have social consequences (e.g., Tajfel \& Turner, 1986) for gender groups (e.g., Fasoli et al., 2018), racial groups (e.g., Singh \& Burns, 2006), nationality groups (e.g., Stoddard \& Leibbrandt, 2014), religious groups (e.g., Rotella, Richeson, Chiao, \& Bean, 2013), or even donor-recipient group relationships 
(Masuda, 2012). People use identity cues to access ingroup identifications (Gaither, Sommers, \& Ambady, 2013). For instance, women can use gender ingroup cues to stereotype their differentiation from men (Casper \& Rothermund, 2012).

However, we know much less about how identity cues influence consumption choices (Ding, Wan, \& Xu, 2017) beyond intentions to signal desirable social identities (Berger \& Heath, 2007; White \& Dahl, 2007). In terms of ethical consumption, people are known to be naturally biased toward helping fellow ingroup members (Cadsby, Du, \& Song, 2016; Line, Hanks, \& Zhang, 2016; Nilsson, Erlandsson, \& Västfjäll, 2016) in donating to charity (Schons, Cadogan, \& Tsakona, 2015), providing reparations for injustices (Ghorbani et al., 2013), feeling moral emotions and reasoning about ethics (Granitz \& Ward, 2001), judging irresponsible corporate behavior (Antonetti \& Maklan, 2016), consuming fair trade products (Doran, 2010), evaluating ethical leadership (Tumasjan, Strobel, \& Welpe, 2011), making unethical decisions (Wood, Noseworthy, \& Colwell, 2013), and favoring domestic products (Gineikiene, Schlegelmilch, \& Auruskeviciene, 2017).

We use the term ethical consumption to indicate actions and purchase decisions made according to ethical concerns (Cooper-Martin \& Holbrook, 1993). Society generally expects business leaders to show ethical behaviors and activities beyond what is expected in legal terms (Carroll, 1979), reflecting concerns about what consumers, employees, shareholders, and the community regard as fair and just protections of stakeholders' moral rights (Carroll, 1991). Therefore, we test ingroup versus outgroup bias across a list of possible ethical topics: fair trade, organic production, empowerment of disadvantaged minorities, and conservation of natural resources (Bray et al., 2011).

Construal Level as Moderating Identity Cues 
Construal level theory (CLT) explains that people perceive objects, events, and people along a continuum, from concrete to abstract, depending on psychological distance from the zero point of the "self, here and now" (Liberman \& Trope, 1998, 2008; Liberman, Trope, McCrea, \& Sherman, 2007). As psychological distance recedes from the zero point, perceivers move from concrete construal involving specific, detailed, context-dependent evaluations regarding "how" actions are performed toward abstract construals involving general, broad, global evaluations regarding "why" actions are performed, beyond specific contextual information (Freitas, Gollwitzer, \& Trope, 2004; Henderson, 2013; Trope \& Liberman, 2010).

Construal level affects identity cues (Ledgerwood \& Callahan, 2012; Luguri \& Napier, 2013; McCrea et al., 2012; Rim, Uleman, \& Trope, 2009; Stephan, Liberman, \& Trope, 2010, 2011). For example, students tend to form abstract views about distant foreign students and form concrete views about local students (Rim et al., 2009). People tend to feel more familiar with close entities and more separated from distant social targets (Stephan et al., 2011). Construal level also influences ethical consumption. For instance, when people use abstract construal for considering immoral behaviors, they respond more severely than when they use concrete construal (Tumasjan et al., 2011). Recycling campaigns are more successful when they focus on abstract benefits rather than concrete harm (White, MacDonnell, \& Dahl, 2011).

We suggest that construal levels will determine responses to ethical consumption. On the one hand, context-specific responses allow individuals to flexibly adapt to the current social environment and guide their behavior (Schwarz, 2007). Consumers using concrete construal will consider specific, detailed contextual information and be more likely to use current social identity cues as optimal behavioral guidelines (Schwarz, 2007; Trope \& 
Liberman, 2010). Thus, we propose that concrete construals will increase the use of identity cues and ingroup bias.

On the other hand, however, ethical consumption requires consistent, long-term behaviors that protect individual well-being regardless of group membership and group biases (Nilsson et al., 2016). For example, successful recycling programs must encourage long-term environmental responsibility and considerations of society as a whole. Considering that identity cues and ingroup biases have such strong contextual influences, how can we elicit consumers to focus on high-level broad principles, values, and enduring views of longterm normative societal standards (Ferguson \& Bargh, 2007; Ledgerwood et al., 2010; Lord \& Lepper, 1999; Torelli \& Kaikati, 2009)? This type of mental inference - high-level motivation, broad, long-term, and context-independent - is related to an abstract way of thinking (abstract construal) (Liberman \& Trope, 1998). Thus, we suggest that abstract construal is key for persuading consumers to act according to their inner goals (Torelli \& Kaikati, 2009) in the interest of both ingroups and outgroups. These observations motivated us to hypothesize:

Hypothesis 1. Construal level will moderate the influence of identity cues on ethical consumption.

Hypothesis 1a. Under salient concrete construal, ingroup cues will have a higher influence on ethical consumption.

Hypothesis $1 b$. Under salient abstract construal, ingroup and outgroup cues will equally influence ethical consumption.

The Mediation of Social Goodwill 
Social goodwill causes individuals to subjectively value benevolence, to desire to give back to society, and to assume social responsibility (Chernev \& Blair, 2015). Accordingly, social goodwill should mediate how construal level and identity cues affect ethical consumption. Under abstract construal, however, people tend to behave according to their inner goals, despite contexts; under concrete construal, they tend to focus on contextual details, social relationships, and group behaviors for creating socially shared viewpoints (e.g., Brennan \& Clark, 1996; Hardin \& Higgins, 1996; Ledgerwood et al., 2010; Turner, 1991). We argue that socially shared viewpoints might then increase social goodwill.

We propose that when consumers' construal level is concrete, they focus on such social identity features of events (e.g., ingroup cues). Under these circumstances, consumer ethical behavior, rather than stemming from consumers' ethical values, is likely to emerge as one way to give back or reciprocate to the socially closer ingroup but not so much to the socially more distant outgroup (a form of ingroup bias). If so, under concrete construal, consumers will show ingroup bias toward close ingroup members, mediated by social goodwill. However, this mediation effect of social goodwill on the impact of social identity cues on ethical consumption should vanish when consumers' construal level is abstract. Under abstract construal, consumers will be focused on broad ethical principles and values over social identity and other secondary features, so social goodwill should lose its mediation effect. This is because, abstract construal focuses on the gist or superordinate features of the events (e.g., broad ethical principles and values), rather than focusing on social identity cues (and other secondary) features. Thus, abstract construal is expected to override ingroup bias and cause ethical consumption to be largely independent of social identity cues.

Consequently, and more important for our second hypothesis, social goodwill will lose its role as a mediator. 
In sum, under concrete construal, social goodwill may act as a mediator of ethical consumption according to identity cues. That is, construal level changes the subjective importance of social goodwill, which in turn, increases ethical consumption (construal level and identity cues $\rightarrow$ social goodwill $\rightarrow$ ethical consumption). We hypothesize that under concrete construal, social goodwill will have higher subjective importance for ingroups, and will increase ingroup bias regarding ethical consumption decisions. However, abstract construal reduces the importance of contextual information; instead, individuals process information according to their inner goals (Torelli \& Kaikati, 2009) and will adopt consistent behaviors without consulting identity cues or being motivated by social goodwill. Formally, we hypothesize:

Hypothesis 2. Social goodwill mediates the impact of identity cues on ethical consumption under salient concrete (vs. abstract) construal.

\section{OVERVIEW OF THE STUDIES}

We conducted four studies to test our proposed theoretical model. In Studies 1-4, we tested the hypothesis that construal level moderates the effects of identity cues on ethical consumption $\left(\mathrm{H}_{1}, \mathrm{H}_{1 \mathrm{a}}, \mathrm{H}_{1 \mathrm{~b}}\right)$, and verified the mediation hypothesis through social goodwill in Study $4\left(\mathrm{H}_{2}\right)$. In Studies 1-3, we activated identity cues to observe ethical consumption decisions in a recycling program, a sustainable product campaign, and a fair trade product campaign. In Study 4, we analyzed naturally occurring gender identity cues in a woman's empowerment initiative. Our studies provide evidence that construal level moderates ingroup 
bias across ethical consumption dimensions, methodological procedures, and samples, increasing the external validity of our findings. Table 2 presents a summary of the studies.

Insert Table 2 about here.

\section{PRETEST FOR STUDY 1}

Before conducting Study 1, we tested perceptions regarding ingroup or outgroup identities separately, with 102 French undergraduate students participating in return for course credit $\left(63.2 \%\right.$ women, $\left.M_{\text {age }}=20.5, S D=1.27\right)$. We based our procedure from the pretest conducted on White and Dahl (2007) to identify ingroups and outgroups. In particular, participants categorized ten identities according to $u s$ for ingroups or them for outgroups. Ingroup categories included me (98.1\%), my best friend (99.1\%), my family (97.2\%), my friends (96.2\%), and a colleague (61.3\%). Outgroup categories included a student in my country $(74.5 \%)$, an acquaintance $(84.9 \%)$, a person in my country $(83.0 \%)$, a person in the world (81.1\%), and a Chinese student (91.5\%). Overall, friend-related cues were most associated with ingroup categorizations, while Asian-related identity cues were most associated with outgroup categorizations. Previous studies have used nationalities as outgroups (e.g., Choi and Winterich, 2013; White and Dahl, 2007; Winterich et al., 2009). More importantly to our context, the pretest results indicate Asian identity cues as an outgroup, being consistent with previous research findings on outgroup cues (Choi and Winterich, 2013; Winterich et al., 2009). Thus, we chose to use university friends as an ingroup identity cue and Asian citizens as an outgroup identity cue. 


\section{STUDY 1: RECYCLING PROGRAM}

The objective of Study 1 was to fully verify our prediction that construal level moderates the effects of identity cues on ethical consumption $\left(\mathrm{H}_{1}, \mathrm{H}_{1 \mathrm{a}}\right.$, and $\left.\mathrm{H}_{1 \mathrm{~b}}\right)$ by analyzing how identity cues relate to recycling intentions.

\section{Participants and Design}

Eighty French undergraduate business students from an introductory marketing course voluntarily participated in Study $1\left(62.5 \%\right.$ women; $\left.M_{\text {age }} 21.3, S D=1.63\right)$, an examination of how construal levels interact with identity cues to influence recycling intentions, using a 2 (construal level: abstract, concrete) x 2 (identity cues: ingroup, outgroup) between-subjects experimental design. Table 3 provides participants' characteristics in the studies.

Insert Table 3 about here.

\section{Procedure and Stimuli}

Participants were first randomly assigned to abstract or concrete construal conditions. To make construal levels salient, we used the "why and how" mindset task adapted from Fujita, Trope, Liberman, and Levin-Sagi (2006). Participants in the abstract condition read this question: "What are your reasons and goals for recycling?" They then followed these instructions: "Use the space below to detail reasons, meanings, and general implications of 
recycling." Participants in the concrete condition read: "What specific products do you recycle and what procedures do you follow? Use the space below to detail concrete recycling steps."

Immediately after completing the construal level manipulation, participants were randomly assigned to ingroup or outgroup identity cue conditions (adapted from Goldstein et al., 2008). Participants in both conditions were told that the International Environmental Organization (IEO) has launched a new recycling program. Those in the ingroup condition were told that the IEO message reads as follows: "Seventy-five percent of our students are participating in our new recycling program. Join your university friends in recycling to preserve the environment." Participants in the outgroup condition read the following message: "Seventy-five percent of Asian citizens are participating in our new recycling program. Join with Asian citizens in recycling to preserve the environment." In this study, we selected only participants that did not define "Asian citizens" as their ingroup, to avoid ingroup bias.

\section{Measures}

Recycling intentions are the main dependent variable in Study 1. Participants indicated their recycling intentions by answering the question: "Do you want to know more about this new recycling program?" Answers were coded 0 (no) or 1 (yes).

\section{Findings}

Manipulation checks and controls. To check whether the "why and how" mindset task manipulated construal level as intended, two independent judges analyzed whether participants provided salient abstract (1), concrete (-1), or neither abstract nor concrete (0) construal level representations (procedure from Liberman \& Trope, 1998). A third judge 
resolved disagreements in 11 cases. A one-way ANOVA showed that construal level manipulation had a significant main effect on construal levels $\left(F_{(1,78)}=699.37, p<.001, \eta_{\mathrm{p}}{ }^{2}\right.$ $=.900)$. Contrasts indicated that participants in the abstract condition provided more abstract representations $(M=.93, S D=.33)$ and that those in concrete construal condition provided more concrete descriptions $(M=-.92, S D=.28)$.

Identity cues manipulation checks comprised two variables: identity importance and identity influence on decisions. Participants evaluated identity importance by answering: "How much importance do you attach to identifying yourself as [a university student/an Asian citizen]?" on a seven-point scale $(1=$ no importance to 7 = great importance $)$. To measure identity influence on decisions we used three items $(\alpha=.740$; Dodds, Monroe, $\&$ Grewal, 1991) answered on a seven-point Likert scale $(1=$ strongly disagree to $7=$ strongly agree): "My thinking is influenced by my perceptions of what [university students, Asian citizens] expect of me"; "My feelings are influenced by my perceptions of what [university students, Asian citizens] expect of me"; and "My actions are influenced by my perceptions of what [university students, Asian citizens] expect of me." One-way ANOVAs demonstrate that the identity cues manipulation had a significant main effect on identity importance $\left(F_{(1}\right.$, $\left.{ }_{78)}=151.03, p<.001, \eta_{\mathrm{p}}^{2}=.659\right)$ and decisions $\left(F_{(1,78)}=40.77, p<.001, \eta_{\mathrm{p}}^{2}=.343\right)$. Contrasts indicated that participants attributed higher importance to ingroup $(M=5.26, S D=$ 1.37) rather than outgroup $(M=1.83, S D=1.24)$ identities and that identities had higher influences on decisions to conform with ingroup $(M=4.58, S D=1.95)$ rather than outgroup $(M=2.19, S D=1.37)$ identities.

To ensure that recommendation conditions rather than advert message credibility evoked recycling intentions, we tested message credibility across three items $(\alpha=.895$, Kukar-Kinney \& Walters, 2003) on a seven-point Likert scale $(1=$ strongly disagree to $7=$ strongly agree): The message "is credible," "speaks the truth," and "corresponds to reality." 
A one-way ANOVA showed that identity cues had no main effect on credibility $\left(F_{(1,78)}=.83\right.$, $\left.n s, \bigcap_{\mathrm{p}}^{2}=.011\right)$. Contrasts indicated that participants in the ingroup $(M=3.72, S D=1.28)$ and outgroup $(M=3.44, S D=1.40)$ conditions attributed similar credibility to both versions of the advertisement, eliminating confounding possibilities. Consequently, the recycling program messages have similar credibility for manipulating identity cues.

Recycling intentions. A 2x2 GLM logistic regression revealed that construal level had a statistically significant effect on the interaction between identity cues and recycling intentions (Wald $\chi_{(1, N=80)}^{2}=5.15, p<.05 ;$ Phi $\varphi=.576$; Cramer's $\left.V=.407\right)$, supporting $\mathrm{H}_{1}$. Wald chi-square tests the significance in logistic regression for a binary outcome variable (recycling intentions: yes, no). A significant Wald test indicates that the parameters associated with the variables are not zero and should be included in the model. Follow-up contrasts showed that participants in the concrete construal condition reported higher recycling intentions $\left(M_{\text {difference }}=.43 ; p=.001\right)$ in response to ingroup cues $(M=.93, S E=$ $.07)$ rather than outgroup cues $(M=.50, S E=.11)$, supporting $\mathrm{H}_{1 \mathrm{a}}$. In addition, participants in the abstract construal condition reported similar recycling intentions $\left(M_{\text {difference }}=-.08 ; n s\right)$ in response to both ingroup $(M=.67, S E=.10)$ and outgroup cues $(M=.75, S E=.10)$, supporting $\mathrm{H}_{1 \mathrm{~b}}$. Figure 2 illustrates how construal level and identity cues interact to affect recycling intentions.

Insert Figure 2 about here.

\section{Discussion}


Study 1 provides evidence that construal level moderates the effects of identity cues on ethical consumption by showing that consumers using concrete construal will respond more strongly to ingroup identity cues, but consumers using abstract construal will rise above ingroup or outgroup identity cues. Thus, we show how construal level effects may counter ingroup biases when consumers make ethical decisions. To enhance external validity, in Study 2 we tested our prediction in a new ethical consumption context.

\section{PRETEST FOR STUDY 2}

Before conducting Study 2, we recruited 61 U.S. consumers from Amazon MTurk $\left(58.3 \%\right.$ men; $\left.M_{\text {age }} 36.4, S D=13.2\right)$ to classify 16 identities as $u s$ or them (procedure from White and Dahl, 2007). Ingroup categories included me (83.6\%), my family (83.3\%), my best friend (77.0\%), U.S. citizens (75.4\%), U.S. consumers (68.3\%), and a school/work colleague (55.0\%). Outgroup categories included European Americans (52.5\%), Latin Americans (53.3\%), African Americans (53.3\%), Asian Americans (55.7\%), an acquaintance (59.0\%), Latin consumers (61.7\%), African consumers (62.3\%), Asian consumers (70.0\%), and European consumers (70.5\%). Participants equally classified people worldwide as both ingroup and outgroup (50.0\%). Furthermore, consistent with previous research on outgroup cues (Choi and Winterich, 2013; Winterich et al., 2009) the pretest results indicate Asian identity cues as an outgroup. Thus, in Study 2 we classified U.S. consumers as the ingroup and Asian consumers as the outgroup.

\section{STUDY 2: SUSTAINABLE PRODUCT}


To further investigate whether construal level moderates ingroup and outgroup cue influences on ethical consumption, in Study 2, we used willingness to pay for a sustainable product as a dependent variable (procedure from Luchs, Naylor, Irwin, \& Raghunathan, 2010). We primed the construal level using a different domain to avoid carry-over effects (Freitas et al., 2004) and we observed a nonstudent sample to enhance the validity of the findings.

\section{Participants and Design}

To examine the interaction effect of construal level and identity cues on willingness to pay for a sustainable product, we recruited 130 U.S. consumers $(56.2 \%$ men, $M=33.7, S D=$ 11.2) through Amazon MTurk in exchange for a fee. To avoid potential issues, we analyzed all data by verifying open-ended questions while checking IPs and duplicate responses. We employed a 2 (construal level: abstract, concrete) x 2 (identity cues: ingroup, outgroup) between subjects experimental design.

\section{Procedure and Stimuli}

Participants were first randomly assigned to a construal level manipulation task adapted from Fujita et al. (2006). Participants in the abstract condition were asked to explain why they should try to maintain and improve their physical health. Participants in the concrete condition were asked to explain how they might do so. We chose the physical health context because it is unrelated to the dependent variable (willingness to pay for a sustainable product) and will avoid carry-over effects.

After participants completed the construal level manipulation task, they were randomly assigned to identity cue conditions (Goldstein et al., 2008), either ingroup U.S. consumers or outgroup Asian consumers. We selected only participants that did not define 
"Asian consumers" as their ingroup, to avoid ingroup bias. They then read the following advertisement for a new sustainable shampoo (Luchs et al., 2010):

Our $24 \mathrm{oz}$. bottle of adult shampoo is available from mass retailers and specialty stores. It has a sustainability rating of 10 (superb) based on pro-environmental and prosocial factors such as sensitivity to pollution and resource usage. A 2016 study showed that $75 \%$ of U.S. [Asian] consumers favor using the shampoo. You can join U.S. [Asian] consumers to help save the environment.

\section{Measures}

Our main dependent variable is willingness to pay for a sustainable product. After participants read the product description and identity cues, they answered an open-ended question: "How much would you be willing to pay for this shampoo?"

\section{Findings}

Manipulation checks and controls. The manipulation check for construal level comprised one item evaluated on a seven-point scale ("To improve and maintain my health, I focus on $\ldots 1=$ why I should do so to $7=$ how I can do so (Burrus \& Roese, 2006). Lower scores indicated abstract construal; higher scores indicated concrete construal. A one-way ANOVA showed that construal level manipulation had a marginally significant main effect on construal levels $\left(F_{(1,128)}=3.07 ; p=.082, \eta_{\mathrm{p}}^{2}=.023\right)$. Contrasts indicated that participants in an abstract mindset focused on the why $(M=3.38, S D=1.72)$; participants in a concrete mindset focused on the how $(M=3.89, S D=1.58)$. As an additional manipulation check, we used the procedure from Study 1 (Liberman \& Trope, 1998). A third judge resolved disagreements in six cases. A one-way ANOVA showed that construal level manipulation had a significant main effect on construal levels $\left(F_{(1,128)}=671.75, p<.001, \eta_{\mathrm{p}}{ }^{2}=.840\right)$. 
Contrasts indicated that participants in the abstract condition provided more abstract representations $(M=.81, S D=.52)$; those in the concrete construal provided more concrete representations $(M=-.97, S D=.17)$.

To check the identity cues manipulation, we asked participants to evaluate whether Asian consumers (1) or U.S. customers (7) favor the shampoo. Lower scores indicated outgroup identity cues; higher scores indicated ingroup identity cues. A one-way ANOVA indicated the main effect of the identity cue manipulation on perceptions regarding those who prefer the product $\left(F_{(1,128)}=8.16 ; p<.01, \eta_{\mathrm{p}}^{2}=.060\right)$. Contrasts indicated that participants in the ingroup condition $(M=4.05, S D=1.65)$ were more likely to name U.S. consumers as favoring the product, compared with participants in the outgroup condition $(M=3.23, S D=$ $1.63)$.

Willingness to pay for a sustainable product. A $2 \times 2$ ANOVA showed that construal level interacted with identity cues to significantly predict willingness to pay $\left(F_{(1,126)}=6.02, p\right.$ $<.05, \eta_{\mathrm{p}}^{2}=.046$ ), additionally supporting $\mathrm{H}_{1}$. Specifically, participants in the concrete construal condition reported higher willingness to pay for the shampoo $\left(F_{(1,126)}=4.06 ; p<\right.$ $.05, \eta_{\mathrm{p}}{ }^{2}=.031$ ) when ingroups favored it (U.S. consumers, $M=10.12, S D=8.01$ ) rather than when outgroups favored it (Asian consumers, $M=6.36, S D=4.00$ ), also supporting $\mathrm{H}_{1 \mathrm{a}}$. In contrast, participants in the abstract construal condition indicated similar willingness to pay $\left(F_{(1,126)}=2.11, n s, \eta_{\mathrm{p}}^{2}=.017\right)$ whether the product was recommended by ingroups (U.S. consumers, $M=7.78, S D=6.08$ ) or outgroups (Asian consumers, $M=10.49, S D=10.58$ ), also supporting $\mathrm{H}_{1 \mathrm{~b}}$. To avoid problems with heterogeneity of variance, we also conducted Welch's ANOVA, that yielded similar results (Welch's ANOVA $=2.84, p<.05)$. Results from this robust test of equality of means further support our predictions and provide converging evidence for our findings. Figure 3 shows how construal level interacted with identity cues to motivate ethical consumption. 
Insert Figure 3 about here.

\section{Discussion}

Consistent with Study 1, Study 2 further indicates that construal moderates the effects of identity cues on ethical consumption: concrete construal increases willingness to pay for a sustainable product only when ingroups rather than outgroups favor it. However, abstract construal increases willingness to pay for the sustainable product without regard to ingroup or outgroup preferences.

\section{STUDY 3: FAIR TRADE PRODUCT}

The objective of Study 3 was to further support our prediction that construal level moderates the effects of identity cues on ethical consumption $\left(\mathrm{H}_{1}\right)$ in a new ethical context: fair trade products. We manipulated identity cues by informing participants that they would be evaluating a consumer-created product (ingroup identity cue) or a company-developed product (outgroup identity cue).

\section{Participants and Design}

We recruited 164 university students $\left(56.8 \%\right.$ men; $\left.M_{\text {age }} 25.9, S D=7.26\right)$ who participated voluntarily, without pay. Study 3 followed a 2 (construal level: abstract, concrete) x 2 (identity cues: ingroup, outgroup) between-subjects experimental design. 


\section{Procedure and Stimuli}

Participants were first randomly assigned to abstract or concrete construal level conditions. Again we adopted the "why and how" mindset task (Fujita et al., 2006; Laran, 2009) and selected academic success as a familiar context unrelated to the dependent variable regarding buying intentions for fair trade products. Participants in the abstract condition indicated why they should pursue academic success; those in the concrete condition indicated how they could do so.

After participants completed the construal level manipulation, they were randomly assigned to ingroup or outgroup identity cue conditions. Participants in both conditions viewed the same fair trade milk packaging image with a clear fair trade label, visible weight information, product and brand image, easy opening system, and vivid colors. We used a fictitious fair trade milk brand to avoid previous attitudes toward products or brands. Participants in the ingroup condition read that "Consumers cooperated in designing this aesthetic fair trade milk packaging." Participants in the outgroup condition read that "The company's design team designed this aesthetic fair trade milk packaging." We selected only participants that did not define "company designers" as their ingroup, to avoid ingroup bias.

\section{Measures}

We measured buying intentions for the fair trade milk with three items $(\alpha=.876$; Dodds et al., 1991) answered on a seven-point Likert scale $(1=$ strongly disagree to $7=$ strongly agree): "I would like to buy this fair trade milk"; "I intend to buy this fair trade milk"; "I believe people should buy this fair trade milk."

We controlled for subjective product knowledge that might explain buying intentions, beyond who designed the product (three items, $\alpha=.917$; Flynn $\&$ Goldsmith, 1999): "I know a lot about food"; "In my circle of friends, I am a food expert"; and "Compared to most other 
people, I know a lot about food," answered on a seven-point Likert scale ( 1 = strongly disagree to $7=$ strongly agree). We used the final part of the questionnaire to gather demographic information.

\section{Findings}

Manipulation checks and controls. The manipulation check for construal level regarding academic success was a one-item nine-point semantic differential scale (Laran, 2009). Specifically, participants evaluated whether they used concrete construal by focusing on "getting my books, studying hard, and going to classes" or abstract construal by "focusing on who I want to be in my personal and professional life." Lower scores related to concrete construal; higher scores to abstract construal. A one-way ANOVA revealed that construal level manipulation had a main effect on construal levels $\left(F_{(1,162)}=4.43 ; p<.05, \eta_{\mathrm{p}}{ }^{2}=.027\right)$. Specifically, participants in the abstract condition $(M=6.75, S D=1.85)$ perceived academic achievement more abstractly than those in the concrete condition $(M=6.08, S D=2.19)$.

To check the manipulation for identity cues, we asked: "Who designed the fair trade milk product?" Participants responded on a seven-point scale $(1=$ company designers to $7=$ consumers like me. Lower scores related to outgroup identity cues; higher scores related to ingroup identity cues. A one-way ANOVA revealed that identity cue manipulation had a main effect on perceptions regarding the packaging origins $\left(F_{(1,162)}=6.35 ; p<.05, \eta_{\mathrm{p}}{ }^{2}=\right.$ .038). Specifically, participants in the ingroup condition $(M=5.67, S D=1.46)$ were more likely to identify consumers as originators; those in the outgroup condition were more likely to identify company designers as originators $(M=5.13, S D=1.30)$.

Fair Trade buying intentions. A two-way ANOVA showed that construal level moderated the effects of identity cues on buying intentions for a fair trade product $\left(F_{(1,160)}=\right.$ 3.94; $\left.p<.05, \eta_{\mathrm{p}}{ }^{2}=.024\right)$, further supporting $\mathrm{H}_{1}$. Specifically, participants in the concrete construal condition indicated higher buying intentions $\left(F_{(1,160)}=23.47 ; p<.001, \eta_{\mathrm{p}}{ }^{2}=.128\right)$ 
under the presence of ingroup identity cues $(M=4.26, S D=1.36)$ rather than outgroup identity cues $(M=2.79, S D=1.36)$, supporting $\mathrm{H}_{1 \mathrm{a}}$. However, participants in the abstract construal condition demonstrated similar levels of buying intentions $\left(F_{(1,160)}=3.82 ; n s, \eta_{\mathrm{p}}^{2}=\right.$ $.023)$ under ingroup $(M=3.72, S D=1.63)$ or outgroup identity cues $(M=3.11, S D=1.19)$, supporting $\mathrm{H}_{1 \mathrm{~b}}$.

\section{Discussion}

Study 3 supports and extends our previous findings by indicating that construal level moderates the influence of ingroup and outgroup cues on ethical consumption. Results reinforce our prediction that ingroup identity cues and concrete construal increase ethical consumption. The study increases external validity by testing a different procedure for identity cues in the ethical consumption context of fair trade products.

\section{PRETEST FOR STUDY 4}

Before we conducted Study 4, we performed a pretest to find a brand that carries neutral perceptions in terms of social responsibility and attitudes. In exchange for a fee, 304 U.S. consumers $\left(53 \%\right.$ men, $\left.M_{\text {age }}=34.7, S D=9.99\right)$ from Amazon MTurk took part in the pretest. Participants were randomly assigned to indicate whether they agreed with Forbes (2018) regarding the ten most valuable brands: Apple (technology), Nike (apparel), CocaCola (beverage), Toyota (automotive), Disney (entertainment), McDonalds (food), GE (home appliances), AT\&T (telecom), Louis Vuitton (luxury), and Walmart (retail), on a seven-point Likert scale $(1=$ highly disagree to $7=$ highly agree $)$. Social responsibility (three items, $\alpha=$ .935; Pinto, Nique, Herter, \& Borges 2016) was measured by "This brand is socially responsible"; "This brand is congruent with my values"; and "This brand has values close to 
mine.” Brand attitude (five items, $\alpha=.979$; Spears $\&$ Singh, 2004) was measured according to “appealing/unappealing, good/bad, pleasant/unpleasant, favorable/unfavorable, and likeable/unlikeable."

The pretest showed that participants perceived the AT\&T brand as neutral for social responsibility $(M=3.73, S D=1.58)$ and attitude $(M=4.21, S D=1.65)$ in that perceptions were not significantly different from the scale midpoint: social responsibility $\left(t_{(30)}=-.933, n s\right)$ and attitude $\left(t_{(30)}=.719, n s\right)$. Thus, in Study 4, we described “AT\&T's Women Empowerment Initiative."

\section{STUDY 4: WOMEN EMPOWERMENT}

In Studies 1-3, we showed how construal level moderates social influences of identity cues on ethical consumption. In Study 4, we proposed and tested whether social goodwill underlies the interaction between construal level and identity cues to motivate ethical consumption $\left(\mathrm{H}_{2}\right)$ of products that support women empowerment. We used participants' gender information as identity cues: women (ingroup) versus men (outgroup).

\section{Participants and Design}

In exchange for a fee, 204 U.S. consumers $(50.5 \%$ women, $M=38.8, S D=11.6)$ were recruited through Amazon MTurk to examine the interaction effect of construal level and identity cues on willingness to patronize a company that supports a socially responsible initiative, and to examine whether social goodwill and other alternative mediators act as underlying mechanism. Study 4 followed a 2 (construal level: abstract, concrete) x 2 (identity cues: ingroup, outgroup) between subjects experimental design. 


\section{Procedure and Stimuli}

Participants were randomly assigned to abstract or concrete construal conditions. Participants in the abstract condition were asked to describe why they should maintain and improve their physical health; participants in the concrete condition were asked to describe how they could do so. The physical health context avoided carry-over effects because it is unrelated to the dependent variable regarding willingness to pay for a product supporting an ethical initiative.

After participants completed the construal level manipulation task, they read about the AT\&T Women Empowerment Initiative:

AT\&T, a world leader in communications, media, entertainment, and technology, has 254,000 employees and operates in more than 90 countries. AT\&T is building a media empire with premium content distributed by streaming services such as HBO Now, DirecTV Now, and Boomerang. Through AT\&T's Women Empowerment Initiative, the company has committed $\$ 400$ million to help provide childcare access and professional development for women employees.

We used gender information to identify women as the ingroup and men as the outgroup. We also analyzed gender differences in the previous studies (Studies 1-3), to ensure that gender identity cues only influenced the results when they were important to the context (i.e., women empowerment). As expected, we did not obtain any gender differences, except for Study 4, which is consistent with our proposition that gender represents ingroup and outgroup cues regarding women empowerment.

\section{Measures}


To measure willingness to pay, we asked "Would you be willing to pay for AT\&T internet services?" answered on a seven-point scale: $1=$ would not pay a premium price to 7 = would pay a premium price. We assessed social goodwill as a mediator variable: "How important do you think it is for companies to give back to society?" (Chernev \& Blair, 2015), evaluated on a seven-point scale $(1=$ not at all important to $7=$ very important $)$.

To examine influences of alternative mediators, we measured several that the literature has identified as important drivers of ethical consumption: human presence (five items, $\alpha=.934$, Gefen $\&$ Straub, 2004), emotional attachment (ten items, $\alpha=.970$, Thomson, MacInnis, \& Park, 2005), source identification (two items, $\alpha=.908$, Thompson \& Malaviya, 2013), brand symbolism (four items, $\alpha=.925$, Morhart, Malär, Guèvremont, Girardin, \& Grohmann, 2015), altruism motives (two items, $\alpha=.875$, Chernev \& Blair, 2015), selfish motives (two items, $\alpha=.710$, Chernev \& Blair, 2015), sacrifice (five items, $\alpha=.918$, Davis, Le, $\&$ Coy, 2011), and status (three items, $\alpha=.708$, O'Cass $\&$ McEwen, 2004), all measured on seven-point scales (Appendix A has additional scale details).

\section{Findings}

Manipulation checks and controls. As before, we used the narratives from the "why and how" mindset task to check for construal manipulation (Liberman \& Trope, 1998). A third judge resolved disagreements in 11 cases. A one-way ANOVA showed that construal level manipulation had a significant main effect on construal $\left(F_{(1,202)}=403.29, p<.001, \eta_{\mathrm{p}}{ }^{2}\right.$ $=.666)$. Contrasts indicated that participants in an abstract condition provided more abstract representations $(M=.58, S D=.77)$; those in the concrete construal condition provided more concrete representations $(M=-.97, S D=.17)$. Welch's ANOVA for heterogeneous variance also yielded similar results (Welch's ANOVA $=382.16, \mathrm{p}<.001$ ). 
By using a well-established company, we needed to control for whether participants were AT\&T clients and, if so, for how long. Chi-square tests showed that our data had a similar percentage distribution of AT\&T clients across identity cues and construal level conditions $\left(\chi_{(204)}^{2}=1.265, n s\right.$; women concrete $=48 \%$, women abstract $=52 \%$, men concrete $=55 \%$, men abstract $=45 \%$ ). In addition, a $2 \times 2$ ANOVA across conditions indicated that participants had used AT\&T services for similar amounts of time $\left(F_{(1,200)}=.445, n s, \eta_{\mathrm{p}}{ }^{2}=\right.$ .002). Thus, we ruled out the possibility of confounding from previous AT\&T experiences.

Willingness to pay for women empowering services. A $2 \times 2$ ANOVA showed that construal level interacted with identity cues to significantly predict willingness to pay for women empowering services $\left(F_{(1,200)}=5.69, p<.05, \eta_{\mathrm{p}}^{2}=.028\right)$, additionally supporting $\mathrm{H}_{1}$. As predicted, participants in the concrete construal condition reported higher willingness to pay $\left(F_{(1,200)}=3.35 ; p=.069, \bigcap_{\mathrm{p}}^{2}=.016\right)$ for ingroups $(M=6.94, S D=1.75)$ rather than outgroups $(M=6.29, S D=2.03)$, also supporting $\mathrm{H}_{1 \mathrm{a}}$. In contrast, participants in the abstract construal condition indicated similar willingness to pay $\left(F_{(1,200)}=2.40, n s, \eta_{\mathrm{p}}^{2}=.012\right)$ whether as ingroups $(M=6.52, S D=1.74)$ or outgroups $(M=7.09, S D=1.73)$, also supporting $\mathrm{H}_{1 \mathrm{~b}}$.

Mediation of Social Goodwill. We analyzed ingroup versus outgroup identity cues and abstract versus concrete construal levels for their effects on ethical consumption through social goodwill. Our framework proposes that under concrete construal, ingroup bias increases social goodwill and mediates the interaction with ethical consumption. To test the theoretical framework, we conducted a moderated-mediation analysis (Hayes, 2013, model 8, $n=5,000)$ and uncovered that the suggested moderated-mediation pathway had a positive, significant indirect effect $(b=.32, S E=.15 ; 95 \%$ confidence interval CI $=[.08, .68])$, supporting $\mathrm{H}_{2}$. Specifically, salient concrete construal caused social goodwill to have a significant indirect effect but not a direct effect (indirect effect $(a \times b)=.34 ; 95 \%$ CI [.12, 
$.62]$; direct effect $[c]=.06, n s)$. Thus, under concrete construal, social goodwill had a stronger mediating effect, while ingroup identity had a weaker direct effect on ethical consumption. In contrast, under salient abstract construal, social goodwill had a nonsignificant indirect effect ( $a \times b=.04 ; 95 \%$ CI $[-.16, .28])$. Identity cues also failed to have a significant direct effect on ethical consumption $(c=-.51, n s)$. Thus, under salient abstract construal, social goodwill had no mediation effect on ethical consumption (Figure 4).

Insert Figure 4 about here.

To understand the influence of additional constructs suggested in the ethical consumption literature, we conducted a moderated-mediation analysis (Hayes, 2013, model 8, $n=5,000)$ with construal level, identity cues (gender), and their interaction, along with the alternative mediators (scaled items averaged) on ethical consumption. Results showed no significant mediation effects for human presence, emotional attachment, source identification, brand symbolism, altruism motives, selfish motives, sacrifice, and status (all $p$ s were nonsignificant). Appendix B shows mediation analysis details, including alternative underlying processes.

\section{Discussion}

Study 4 extends our previous findings and has important theoretical and practical implications for companies investing in empowerment initiatives. First, we show that identity cues and construal levels affect ethical consumption via social goodwill. That is, consumers using concrete construal subjectively value social goodwill and ethical consumption that 
favors ingroups. However, alternative mediators suggested in the literature fail to influence the effects of identity cues and construal level on ethical consumption.

\section{GENERAL DISCUSSION}

The business ethics literature and marketing practitioners have long believed that ingroup biases and cues can be used effectively to influence ethical consumption decisions (e.g., Antonetti \& Maklan, 2016; Garcia et al., 2010; Granitz \& Ward, 2001). To investigate those assumptions, we conducted four studies and found converging evidence that ingroup biases indeed enhance ethical consumption, but only under abstract construal allowing ingroup and outgroup cues to have similar influences on ethical consumption.

In experimental Studies 1-4, we find that construal level moderates the influence of identity cues on ethical consumption decisions in recycling, sustainability, fair trade, and women empowerment contexts. In Studies 1-3, the ingroup bias effect occurs among study participants who have received identity cues. In Study 4, the effect is observed among naturally occurring gender groups. The effect holds across several "why and how" construal manipulations regarding recycling (Study 1), maintaining physical health (Studies 2 and 4), and achieving academic success (Study 3). In Study 4, we show that the subjective importance of social goodwill mediates the effect. We also analyze possible alternative explanations provided in the ethical consumption literature.

\section{Theoretical Contributions}

Our findings have several theoretical and managerial implications and indicate directions for future research. We contribute to business ethics literature (e.g., Antonetti \& 
Maklan, 2016; Ghorbani et al., 2013; Schons et al., 2015), by demonstrating that identity cues and construal levels have effects in various consumption contexts. First, activated ingroup identity cues are thought to motivate ethical decisions (Berger \& Heath, 2007; Escalas \& Bettman, 2005; Oyserman, 2009), especially in business ethics contexts (Antonetti \& Maklan, 2016; Granitz \& Ward, 2001). As an extension, we reveal that abstract construal moderates the effects of ingroup biases on ethical consumption decisions.

Second, ethical consumption research has separated construal influences (e.g., Irmak, Wakslak, \& Trope, 2013) from identity influences (e.g., Oyserman, 2013), but we observe the previously overlooked interaction between ingroup and outgroup identities and construal levels. By showing downstream effects on ethical consumption, we contribute to CLT and social influence literature (e.g., Ledgerwood \& Callahan, 2012; Luguri \& Napier, 2013; McCrea et al., 2012; Zhao \& Xie, 2011).

Third, researchers have demonstrated that ingroup cues can increase ethical consumption (e.g., Torelli \& Kaikati, 2009); others suggest that outgroup cues motivate ethical behavior (e.g., Griskevicius, Tyber, \& Bergh, 2010). To reconcile the contradictions, we draw on construal level and social influence (Ledgerwood \& Callahan, 2012; Ledgerwood et al., 2010; Luguri \& Napier, 2013; McCrea et al., 2012) to show that consumers using concrete construal focus on social contextual cues and are thus more influenced by ingroups rather than outgroups, reinforcing the ingroup bias effect. However, abstract construal reduces ingroup bias so that consumers align their behaviors with their inner goals. Consequently, ingroups and outgroups have equal influences on ethical consumption.

Fourth, we contribute to the literature by exploring the subjective importance of social goodwill as a force underlying influences of identity cues and construal level (Chernev \& Blair, 2015). Based on arguments regarding construal level and contextual influence 
(Ledgerwood et al., 2010), we propose that social goodwill can motivate ethical consumption, but construal level is a boundary condition that changes the influence. That is, under concrete construal, social goodwill mediates ethical consumption aligned with social identity cues, but under abstract construal, ethical values are more important than contextual information (Torelli \& Kaikati, 2009). As a result, ethical consumption is not mediated by social goodwill but rather relies on ethical value consistency. By doing so, we contribute to recent research (Chernev \& Blair, 2015) showing under which conditions the mediation of social goodwill predicts ethical consumption. We also extend previous findings on construal level fit (e.g., McCrea et al., 2012; Zhao \& Xie, 2011) and identity-based motivation (Oyserman, 2009, 2013).

\section{Managerial and Social Implications}

We also provide important managerial and social implications regarding strategies and public policies for enhancing ethical consumption and reducing adverse environmental and social impacts (Paavola, 2001; Schaefer \& Crane, 2005). We show that managers and public policymakers may fail to enhance ethical consumption when they use ingroup bias strategies. Instead, we suggest that they combine identity cues and construal levels to foster ethical consumption.

Concrete construal and ethical consumption. We recommend that managers and public policymakers using campaigns that focus on concrete construal should ensure that ingroup identity cues are salient, especially when they are introducing new ethical products or services. For example, the Always campaign slogan Like a Girl countered the public stigma that girls are weaker and slower than boys by showing girls excelling in many activities, a concrete construal that effectively appealed to the intended ingroup target. In 2016, the WWF created a campaign called We Love Cities to raise awareness about the need for cities 
worldwide to focus on sustainability. The campaign urges consumers to "join the millions of people shaping the future of sustainable cities all over the world." We propose that WWF might be more successful by focusing on concrete construal, by asking people to think about how cities can be sustainable and by highlighting ingroup recommendations. For example, an advertisement that says, "Join people of your city" would associate concrete construal and ingroup cues. In addition, our findings imply that customers might have increased social goodwill and willingness to pay premium prices for products or services if brands that support ethical causes use concrete construal to emphasize relevance for ingroups. Such strategies can have positive impacts on society by increasing ethical consumption while positively enhancing company profits.

Abstract construal and ethical consumption. We counsel that ethical consumption campaigns for broad audiences can mitigate ingroup bias effects by activating abstract construal. Thus, we advise that managers and public policymakers invest in campaigns that focus on abstract construal, such as focusing on "why," so that ingroup and outgroup cues will similarly impact ethical consumption and ensure that ethical consumption is more consistent. In contrast, concrete construal increases the focus on contextual cues. For example, Ben \& Jerry's ice cream is known as a fair trade product. The company can appeal to both outgroup and ingroup customers through abstract construal emphasizing "why" consumers should consume fair trade products. Another example of a public policy was launched by the Canadian city Calgary, which created a recycling program campaign explaining "why" the population should recycle (White et al., 2011). Consumers would form similar recycling intentions if the initiative reinforced ingroup cues by referring to recommendations from "Canadian friends" or the "local community" or by reinforcing outgroup cues by referring to "European citizens." 


\section{Limitations and Future Research}

Despite our contributions, our study presents limitations that also represent opportunities for further studies. First, we activated construal levels through the "why and how" mindset task. Other manipulations, such as temporal distance, might be used to activate construal levels (e.g., Chang \& Pham, 2013). Thus, a campaign might emphasize shorter rather than longer temporal distance (e.g., Save the planet now vs. later). Additionally, future studies should measure whether participants have chronic construal levels (e.g., Vallacher \& Wegner, 1987).

We activated ingroup and outgroup identities through cues such as recommendations (Studies 1-3) and naturally occurring groups (Study 4). Future studies can manipulate identity cues using other variables such as politeness and perceived familiarity (Stephan et al., 2010, 2011). Moreover, social identities can also be classified as associative (increased preference for identity-linked recommendations) or dissociative (avoidance of identity-linked recommendations) (White \& Dahl, 2007), which should be tested in future studies of ethical consumption.

\section{Acknowledgments}

The authors acknowledge Yaacov Trope, Darren Dahl, Carlos Torelli, and Alison Ledgerwood for their insightful comments during early stages of this research. The authors also thank BEQ associate editor and anonymous reviewers for their insightful comments. 
References

Aaker, J. L., \& Akutsu, S. 2009. Why do people give? The role of identity in giving. Journal of Consumer Psychology, 19: 267-270.

Antonetti, P., \& Maklan, S. J. 2016. Identity bias in negative word of mouth following irresponsible corporate behavior: A research model and moderating effects. Journal of Business Ethics, 149(4): 1005-1023.

Axt, J. R., Nguyen, H., \& Nosek, B. A. 2018. The judgment bias task: A flexible method for assessing individual differences in social judgment biases. Journal of Experimental Social Psychology, 76: 337-355.

Barbarossa, C., \& De Pelsmacker, P. 2016. Positive and negative antecedents of purchasing eco-friendly products: A comparison between green and non-green consumers. Journal of Business Ethics, 134(2): 229-247.

Berger, J., \& Heath, C. 2007. Where consumers diverge from others: Identity-signaling and product domains. Journal of Consumer Research, 34: 121-134.

Bray, J., Johns, N., \& Kilburn, D. 2011. An exploratory study into the factors impeding ethical consumption. Journal of Business Ethics, 98(4): 597-608.

Brennan, S. E., \& Clark, H. H. 1996. Conceptual pacts and lexical choice in conversation. Journal of Experimental Psychology: Learning, Memory, and Cognition, 22(6): 1482.

Brewer, M. B. 1999. The psychology of prejudice: Ingroup love and outgroup hate? Journal of Social Issues, 55(3): 429-444.

Burrus, J., \& Roese, N. J. 2006. Long ago it was meant to be: The interplay between time, construal, and fate beliefs. Personality and Social Psychology Bulletin, 32(8): 10501058. 
Cadsby, C. B., Du, N., \& Song, F. 2016. In-group favoritism and moral decisionmaking. Journal of Economic Behavior \& Organization, 128: 59-71.

Carrigan, M., \& Attalla, A. 2001. The myth of the ethical consumer-do ethics matter in purchase behavior? Journal of Consumer Marketing, 18(7): 560-578.

Carroll, A. B. 1979. A three-dimensional conceptual model of corporate performance. Academy of Management Review, 4(4): 497-505.

Carroll, A. B. 1991. The pyramid of corporate social responsibility: Toward the moral management of organizational stakeholders. Business Horizons, 34(4): 39-48.

Casper, C., \& Rothermund, K. 2012. Gender self-stereotyping is context dependent for men but not for women. Basic and Applied Social Psychology, 34(5): 434-442.

Chang, H., \& Pham, M. 2013. Affect as a decision-making system of the present. Journal of Consumer Research, 40: 42-63.

Chernev, A., \& Blair, S. 2015. Doing well by doing good: The benevolent halo of corporate social responsibility. Journal of Consumer Research, 41(6): 1412-1425.

Choi, W. J., \& Winterich, K. P. 2013. Can brands move in from the outside? How moral identity enhances out-group brand attitudes. Journal of Marketing, 77(2): 96-111.

Cooper-Martin, E. \& M. B. Holbrook. 1993. Ethical consumption experiences and ethical space. Advances in Consumer Research, 20(1): 113-118.

Davis, J. L., Le, B., \& Coy, A. E. 2011. Building a model of commitment to the natural environment to predict ecological behavior and willingness to sacrifice. Journal of Environmental Psychology, 31(3): 257-265.

De Pelsmacker, P., L. Driesen \& G. Rayp. 2005. Do consumers care about ethics? Willingness to pay for fair trade coffee. Journal of Consumer Affairs, 39(2): 363385. 
Ding, Y., Wan, E. W., \& Xu, J. 2017. The impact of identity breadth on consumer preference for advanced products. Journal of Consumer Psychology, 27(2): 231-244.

Dodds, W., Monroe, K., \& Grewal, D. 1991. Effects of price, brand, and store information on buyers' product evaluations. Journal of Marketing Research, 28(3): 307-319.

Doran, C. J. J. 2010. Fair trade consumption: In support of the outgroup. Journal of Business Ethics, 95(4): 527-541.

Escalas, J. E., \& Bettman, J. R. 2005. Self-construal, reference groups, and brand meaning. Journal of Consumer Research, 32(3): 378-389.

Fasoli, F., Cadinu, M., Carnaghi, A., Galdi, S., Guizzo, F., \& Tassara, L. 2018. How do you self-categorize? Gender and sexual orientation self-categorization in homosexual/heterosexual men and women. Personality and Individual Differences, 123: 135-139.

Ferguson, M. J., \& Bargh, J. A. 2007. Beyond the attitude object: Automatic attitudes spring from object-centered-contexts. Implicit Measures of Attitudes, 216-246.

Flynn, L. R., \& Goldsmith, R. E. 1999. A short, reliable measure of subjective knowledge. Journal of Business Research, 46(1): 57-66.

Forbes. 2018. The world's most valuable brands. Available from: https://www.forbes.com/powerful-brands/list/

Freitas, A. L., Gollwitzer, P., \& Trope, Y. 2004. The influence of abstract and concrete mindsets on anticipating and guiding others' self-regulatory efforts. Journal of Experimental Social Psychology, 40(6): 739-752.

Fujita, K., Trope, Y., Liberman, N., \& Levin-Sagi, M. 2006. Construal levels and selfcontrol. Journal of Personality and Social Psychology, 90(3): 351-367. 
Gaither, S. E., Sommers, S. R., \& Ambady, N. 2013. When the half affects the whole: Priming identity for biracial individuals in social interactions. Journal of Experimental Social Psychology, 49(3): 368-371.

Garcia, M., Bazerman, S., Kopelman, M., Tor, S., \& Miller, D. T. 2010. The price of equality: Suboptimal resource allocations across social categories. Business Ethics Quarterly, 20(1): 75-88.

Gefen, D., \& Straub, D. W. 2004. Consumer trust in B2C e-commerce and the importance of social presence: Experiments in e-products and e-services. Omega, 32(6): 407-424.

Ghorbani, M., Liao, Y., Çayköylü, S., \& Chand, M. 2013. Guilt, shame, and reparative behavior: The effect of psychological proximity. Journal of Business Ethics, 114(2): 311-323.

Gineikiene, J., Schlegelmilch, B. B., \& Auruskeviciene, V. 2017. “Ours” or “theirs”? Psychological ownership and domestic products preferences. Journal of Business Research, 72: 93-103.

Goldstein, N. J., Cialdini, R. B., \& Griskevicius, V. 2008. A room with a viewpoint: Using social norms to motivate environmental conservation in hotels. Journal of Consumer Research, 35(3): 472-482.

Granitz, N. A., \& Ward, J. C. 2001. Actual and perceived sharing of ethical reasoning and moral intent among ingroup and outgroup members. Journal of Business Ethics, 33(4): 299-322.

Griskevicius, V., Tybur, J. M., \& Bergh, B. V. 2010. Going green to be seen: Status, reputation, and conspicuous conservation. Journal of Personality and Social Psychology, 98(3): 392-404. 
Hardin, C. D., \& Higgins, E. T. 1996. Shared reality: How social verification makes the subjective objective. In R. M. Sorrentino \& E. T. Higgins (Eds.), Handbook of Motivation and Cognition, vol. 3: 28-84. New York, NY: Guilford Press.

Hayes, A. F. 2013. Introduction to mediation, moderation, and conditional process analysis: A regression-based approach. New York: Guilford Press.

Henderson, M. D. 2013. When seeing the forest reduces the need for trees: The role of construal level in attraction to choice. Journal of Experimental Social Psychology, 49(4): 676-683.

Irmak, C., Wakslak, C. J., \& Trope, Y. 2013. Selling the forest, buying the trees: The effect of construal level on seller-buyer price discrepancy. Journal of Consumer Research, 40(2): 284-297.

Kidwell, B., Farmer, A., \& Hardesty, D. M. 2013. Getting liberals and conservatives to go green: Political ideology and congruent appeals. Journal of Consumer Research, 40(2): $350-367$.

Kirmani, A. 2009. The self and the brand. Journal of Consumer Psychology, 19(3): 271-275.

Kukar-Kinney, M., \& Walters, R. G. 2003. Consumer perceptions of refund depth and competitive scope in price-matching guarantees: effects on store patronage. Journal of Retailing, 79(3): 153-160.

Laran, J. 2009. Choosing your future: Temporal distance and the balance between selfcontrol and indulgence. Journal of Consumer Research, 36(6): 1002-1015.

Ledgerwood, A., \& Callahan, S. P. 2012. The social side of abstraction: Psychological distance enhances conformity to group norms. Psychological Science, 23: 907-913.

Ledgerwood, A., Trope, Y., \& Chaiken, S. 2010. Flexibility now, consistency later:

Psychological distance and construal shape evaluative responding. Journal of Personality and Social Psychology, 99(1): 32-51. 
Liberman, N., \& Trope, Y. 1998. The role of feasibility and desirability considerations in near and distant future decisions: A test of temporal construal theory. Journal of Personality and Social Psychology, 75(1): 5-18.

Liberman, N., \& Trope, Y. 2008. The psychology of transcending the here and now. Science, 322(5905): 1201-1205.

Liberman, N., Trope, Y., McCrea, S. M., \& Sherman, S. J. 2007. The effect of level of construal on the temporal distance of activity enactment. Journal of Experimental Social Psychology, 43(1): 143-149.

Line, N. D., Hanks, L., \& Zhang, L. 2016. Sustainability communication: The effect of message construals on consumers' attitudes towards green restaurants. International Journal of Hospitality Management, 57: 143-151.

Lord, C. G., \& Lepper, M. R. 1999. Attitude representation theory. In Advances in Experimental Social Psychology, vol. 31: 265-343. Academic Press.

Luchs, M. G., Naylor, R., Irwin, J., \& Raghunathan, R. 2010. The sustainability liability: Potential negative effects of ethicality on product preference. Journal of Marketing, 74(5): 18-31.

Luguri, J. B., \& Napier, J. L. 2013. Of two minds: The interactive effect of construal level and identity on political polarization. Journal of Experimental Social Psychology, 49(6): 972-977.

Masuda, N. 2012. Ingroup favoritism and intergroup cooperation under indirect reciprocity based on group reputation. Journal of Theoretical Biology, 311: 8-18.

McCrea, S., Wieber, F., \& Myers, A. L. 2012. Construal level mind-sets moderate self-and social stereotyping. Journal of Personality and Social Psychology, 102(1): 51-68. 
Morhart, F., Malär, L., Guèvremont, A., Girardin, F., \& Grohmann, B. 2015. Brand authenticity: An integrative framework and measurement scale. Journal of Consumer Psychology, 25(2): 200-218.

Mullen, B., Brown, R., \& Smith, C. 1992. Ingroup bias as a function of salience, relevance, and status: An integration. European Journal of Social Psychology, 22(2): 103-122.

Nicholls, A. \& N. Lee. 2006. Purchase decision-making in fair trade and the ethical purchase "gap": Is there a fair trade "twix"? Journal of Strategic Marketing, 14(4): 369-386.

Nilsson, A., Erlandsson, A., \& Västfjäll, D. 2016. The congruency between moral foundations and intentions to donate, self-reported donations, and actual donations to charity. Journal of Research in Personality, 65: 22-29.

O'Cass, A., \& McEwen, H. 2004. Exploring consumer status and conspicuous consumption. Journal of Consumer Behaviour, 4(1): 25-39.

Oyserman, D. 2009. Identity-based motivation: Implications for action-readiness, proceduralreadiness, and consumer behavior. Journal of Consumer Psychology, 19(3): 250-260.

Oyserman, D. 2013. Not just any path: Implications of identity-based motivation for disparities in school outcomes. Economics of Education Review, 33: 179-190.

Paavola, J. 2001. Towards sustainable consumption: Economics and ethical concerns for the environment in consumer choices. Review of Social Economy, 59(2): 227-248.

Pinto, D. C., Nique, W. M., Herter, M. M., \& Borges, A. 2016. Green consumers and their identities: How identities change the motivation for green consumption. International Journal of Consumer Studies, 40(6): 742-753.

Prothero, A., McDonagh, P., \& Dobscha, S. 2010. Is green the new black? Reflections on a green commodity discourse. Journal of Macromarketing, 30(2): 147-159. 
Rim, S. Y., Uleman, J. S., \& Trope, Y. 2009. Spontaneous trait inference and construal level theory: Psychological distance increases nonconscious trait thinking. Journal of Experimental Social Psychology, 45(5): 1088-1097.

Rotella, K. N., Richeson, J. A., Chiao, J. Y., \& Bean, M. G. 2013. Blinding trust: The effect of perceived group victimhood on intergroup trust. Personality and Social Psychology Bulletin, 39(1): 115-127.

Schaefer, A., \& Crane, A. 2005. Addressing sustainability and consumption. Journal of Macromarketing, 25(1): 76-92.

Schons, L. M., Cadogan, J., \& Tsakona, R. 2017. Should charity begin at home? An empirical investigation of consumers' responses to companies' varying geographic allocations of donation budgets. Journal of Business Ethics, 114(3): 559-576.

Schwarz, N. 2007. Attitude construction: Evaluation in context. Social Cognition, 25(5): 638-656.

Shavitt, S., Torelli, C. J., \& Wong, J. 2009. Identity-based motivation: constraints and opportunities in consumer research. Journal of Consumer Psychology, 19(3): 261266.

Singh, S. P., \& Burns, T. 2006. Race and mental health: There is more to race than racism. British Medical Journal BMJ, 333(7569), 648-651.

Stephan, E., Liberman, N., \& Trope, Y. 2010. Politeness and psychological distance: A construal level perspective. Journal of Personality and Social Psychology, 98(2): 268-280.

Stephan, E., Liberman, N., \& Trope, Y. 2011, The effects of time perspective and level of construal on social distance, Journal of Experimental Social Psychology, 47(2): $397-$ 402. 
Stoddard, O., \& Leibbrandt, A. 2014. An experimental study on the relevance and scope of nationality as a coordination device. Economic Inquiry, 52(4): 1392-1407.

Tajfel, H., \& Turner, J. C. 1979. An integrative theory of intergroup conflict. In W. G. Austin and S. Worchel (Eds.), The Social Psychology of Intergroup Relations. Monterey, CA: Brooks/Cole.

Tajfel, H., \& Turner, J. C. 1986. The social identity theory of intergroup behavior. Psychology of Intergroup Relations, 7-24.

Thompson, D. V., \& Malaviya, P. 2013. Consumer-generated ads: Does awareness of advertising co-creation help or hurt persuasion? Journal of Marketing, 77(3): 33-47.

Thomson, M., MacInnis, D. J., \& Park, C. W. 2005. The ties that bind: Measuring the strength of consumers' emotional attachments to brands. Journal of Consumer Psychology, 15(1), 77-91.

Thorne, L., Massey, D. W., \& Jones, J. 2004. An investigation of social influence: Explaining the effect of group discussion on consensus in auditors' ethical reasoning. Business Ethics Quarterly, 14(3): 525-551.

Torelli, C. J., \& Kaikati, A. M. 2009. Values as predictors of judgments and behaviors: The role of abstract and concrete mindsets. Journal of Personality and Social Psychology, 96: 231-247.

Trope, Y., \& Liberman, N. 2010. Construal-level theory of psychological distance. Psychological Review, 117(2): 440-463.

Trope, Y., Liberman, N., \& Wakslak, C. 2007. Construal levels and psychological distance: Effects on representation, prediction, evaluation, and behavior. Journal of Consumer Psychology, 17: 83-95. 
Tumasjan, A., Strobel, M., \& Welpe, I. 2011. Ethical leadership evaluations after moral transgression: Social distance makes the difference. Journal of Business Ethics, 99(4): 609-622.

Turner, J. C. 1991. Mapping social psychology series. Social influence. Belmont: Thomson Brooks/Cole Publishing Co.

Turner, J. C., Hogg, M. A., Oakes, P. J., Reicher, S. D., \& Wetherell, M. S. 1987.

Rediscovering the social group: A self-categorization theory. New York: Blackwell.

Turner, J. C., Brown, R. J., \& Tajfel, H. 1979. Social comparison and group interest in ingroup favouritism. European Journal of Social Psychology, 9(2): 187-204.

Vallacher, R. R., \& Wegner, D. M. 1987. What do people think they're doing? Action identification and human behavior. Psychological Review, 94(1), 3-15.

Vermue, M., Seger, C. R., \& Sanfey, A. G. 2018. Group-based biases influence learning about individual trustworthiness. Journal of Experimental Social Psychology, 77: $36-49$.

White, K., \& Dahl, D. W. 2007. Are all out-groups created equal? Consumer identity and dissociative influence. Journal of Consumer Research, 34(4): 525-536.

White, K., MacDonnell, R., \& Dahl, D. W. 2011. It's the mind-set that matters: The role of construal level and message framing in influencing consumer efficacy and conservation behaviors. Journal of Marketing Research, 48(3): 472-485.

Winterich, K. P., Mittal, V., \& Ross Jr, W. T. 2009. Donation behavior toward in-groups and out-groups: The role of gender and moral identity. Journal of Consumer Research, 36(2): 199-214.

Wood, M. O., Noseworthy, T. J., \& Colwell, S. R. 2013. Might just cut down the forest: The perils of forced choice on "seemingly" unethical decision making. Journal of Business Ethics, 118(3): 515-527. 
Zabel, H. U. 2005. A model of human behaviour for sustainability. International Journal of Social Economics, 32(8): 717-734.

Zhao, M., \& Xie, J. 2011. Effects of social and temporal distance on consumers' responses to peer recommendations. Journal of Marketing Research, 48(3): 486-496. 


\section{FIGURES AND TABLES}

Figure 1. Construal Level and Social Influence on Ethical Consumption

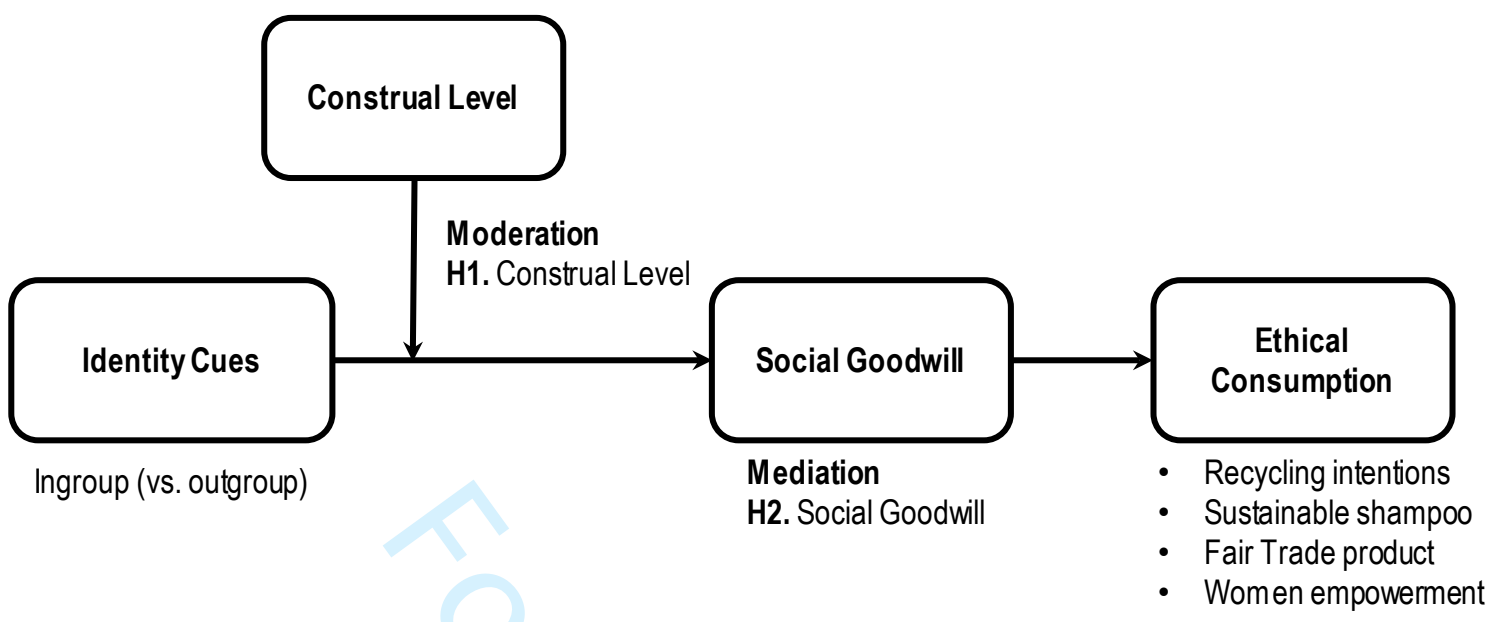


Figure 2. Construal Level and Identity Cue Effects on Ethical Consumption in Study 1

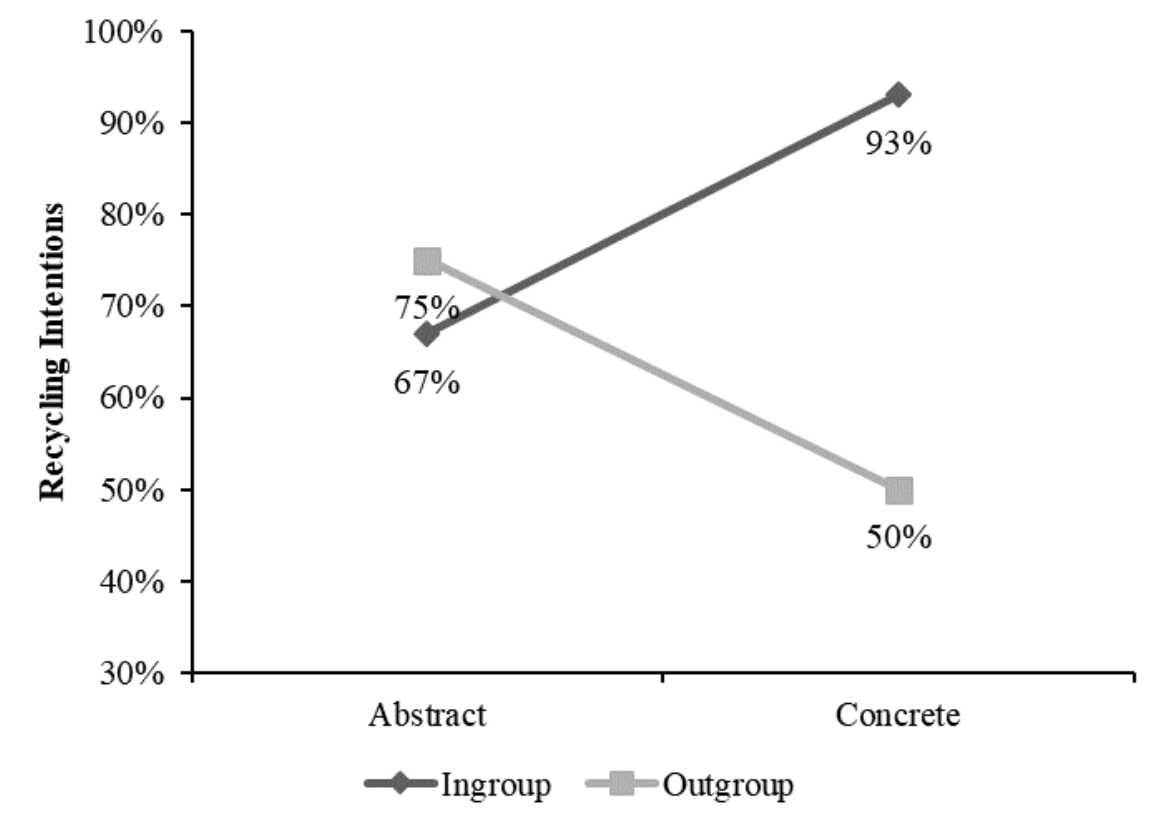


Figure 3. Construal Level and Identity Cue Effects on Ethical Consumption in Study 2

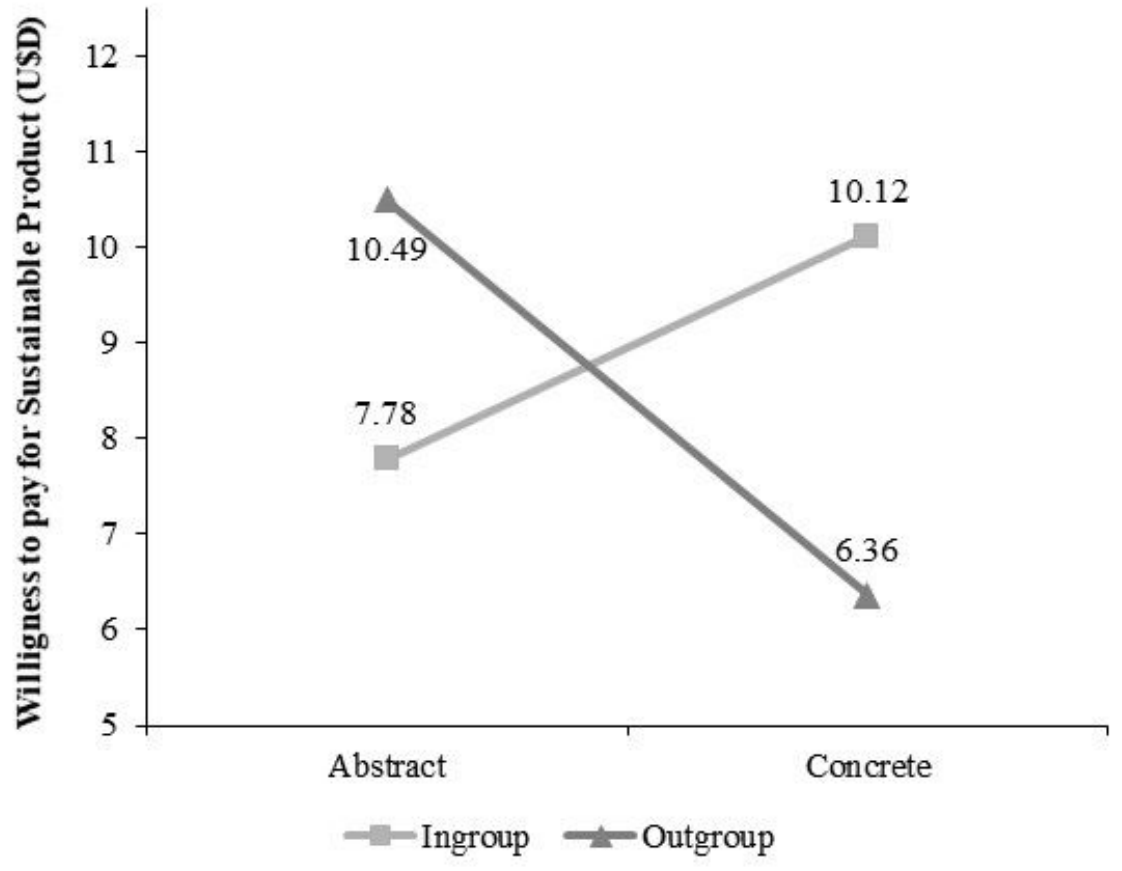


Figure 4. Social Goodwill Effects on Ethical Consumption in Study 4

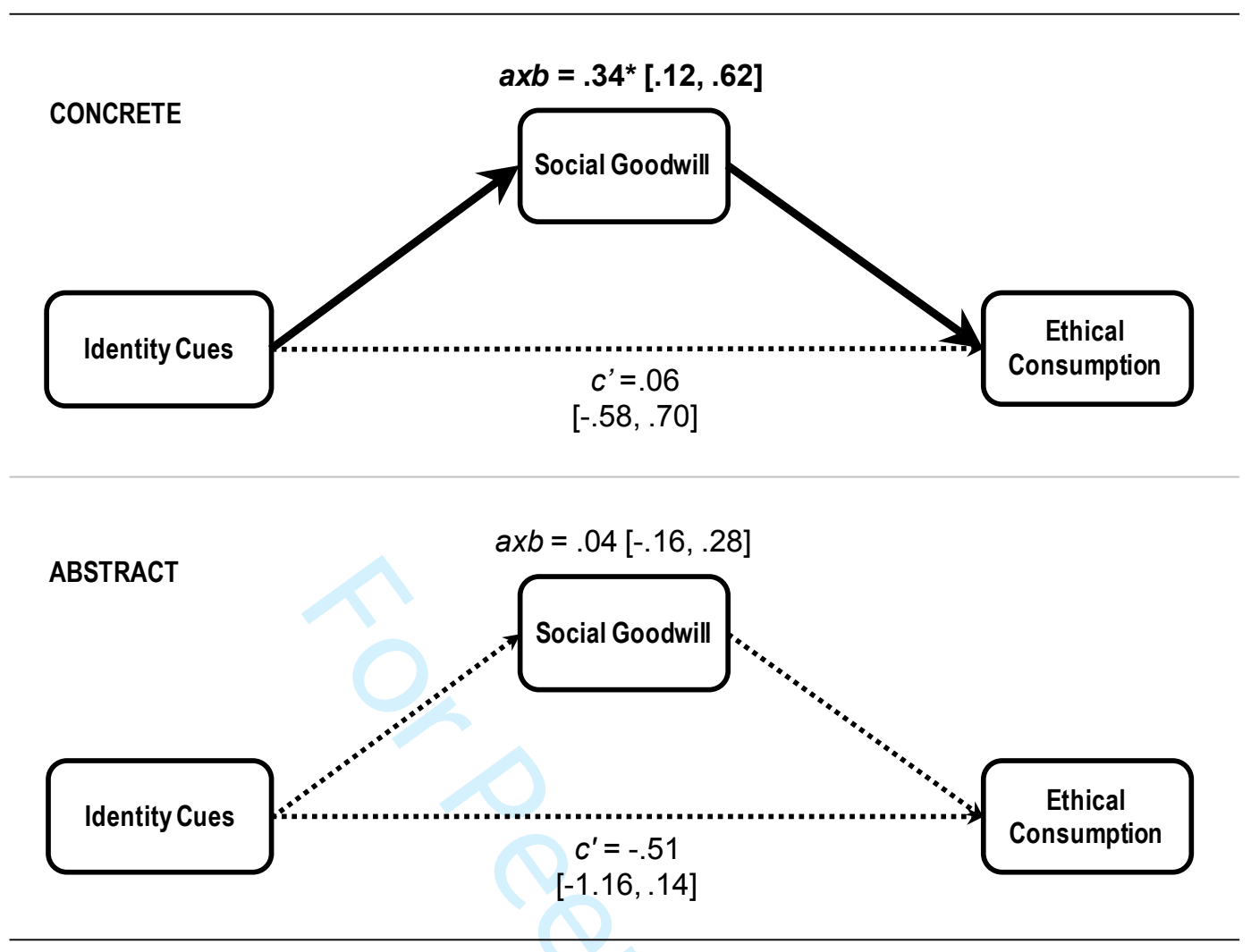

Notes. Social goodwill fully mediated the effect of ingroup versus outgroup gender identity cues on ethical consumption in Study 4. Dashed lines indicate nonsignificant statistical paths. Bracketed numbers indicate $95 \%$ CIs. $* p<.05, * * p<.01, * * * p<.001$. 
Table 1. Summary of concepts used

\begin{tabular}{|c|c|c|c|}
\hline Concepts & Description & Sources & $\begin{array}{l}\text { Dimensions used } \\
\text { in this study }\end{array}$ \\
\hline Ingroup Bias & $\begin{array}{l}\text { Ingroup bias indicates "intended or } \\
\text { unintended favoritism in evaluation, } \\
\text { judgment, or behavior for one social group } \\
\text { over another." }\end{array}$ & $\begin{array}{l}\text { Axt et al. (2018, p. } \\
337) \\
\text { Brewer (1999) } \\
\text { Mullen et al. (1992) } \\
\text { Tajfel \& Turner (1979) } \\
\text { Turner et al. (1987) }\end{array}$ & $\begin{array}{l}\text { Ingroups versus } \\
\text { outgroups }\end{array}$ \\
\hline Identity Cues & $\begin{array}{l}\text { Identity cues are constructed according to } \\
\text { context. They can activate readiness to act } \\
\text { in terms of the norms, values, and } \\
\text { behaviors relevant to the identity. } \\
\text { Ingroup cues (us) come from closely } \\
\text { attached family, friends, colleagues, and } \\
\text { fellow citizens. Outgroup cues (them) } \\
\text { come from distant groups such as } \\
\text { individuals from other universities, } \\
\text { companies, and countries. }\end{array}$ & $\begin{array}{l}\text { Aaker \& Akutsu (2009) } \\
\text { Kirmani (2009) } \\
\text { Shavitt et al. (2009) } \\
\text { Oyserman }(2009,2013) \\
\text { Tajfel \& Turner (1979) } \\
\text { Turner et al. (1987) }\end{array}$ & $\begin{array}{l}\text { Ingroups versus } \\
\text { outgroups }\end{array}$ \\
\hline $\begin{array}{l}\text { Construal } \\
\text { Level }\end{array}$ & $\begin{array}{l}\text { Construal level theory (CLT) explains that } \\
\text { people think along a concrete to abstract } \\
\text { continuum, depending on psychological } \\
\text { distance. } \\
\text { Consumers in concrete construal tend to } \\
\text { analyze specific and detailed contextual } \\
\text { information. Consumers in abstract } \\
\text { construal tend to process more globally } \\
\text { and broadly. }\end{array}$ & $\begin{array}{l}\text { Freitas et al., (2004) } \\
\text { Henderson (2013) } \\
\text { Liberman \& Trope } \\
(1998,2008) \\
\text { Liberman et al. (2007) } \\
\text { Trope \& Liberman } \\
(2010)\end{array}$ & $\begin{array}{l}\text { Concrete versus } \\
\text { abstract construal }\end{array}$ \\
\hline $\begin{array}{l}\text { Social } \\
\text { Goodwill }\end{array}$ & $\begin{array}{l}\text { Social goodwill indicates subjective } \\
\text { values regarding the importance of giving } \\
\text { back to society. }\end{array}$ & $\begin{array}{l}\text { Chernev \& Blair } \\
\text { (2015) }\end{array}$ & Social goodwill \\
\hline $\begin{array}{l}\text { Ethical } \\
\text { Consumption }\end{array}$ & $\begin{array}{l}\text { Ethical consumption indicates decision- } \\
\text { making, purchases, and consumption } \\
\text { experiences aligned with ethical concerns } \\
\text { about "what consumers, employees, } \\
\text { shareholders, and the community regard as } \\
\text { fair, just, or in keeping with the respect or } \\
\text { protection of stakeholders' moral rights" }\end{array}$ & $\begin{array}{l}\text { Cooper-Martin \& } \\
\text { Holbrook (1993). } \\
\text { Carroll }(1991, \text { p. } 41)\end{array}$ & $\begin{array}{l}\text { Organic products } \\
\text { Fair trade } \\
\text { Sustainable products } \\
\text { Recycling } \\
\text { Women empowerment }\end{array}$ \\
\hline
\end{tabular}


Table 2. Summary of the Studies

\begin{tabular}{|c|c|c|c|c|c|c|}
\hline Study & $\begin{array}{l}\text { Sample } \\
\text { Size }\end{array}$ & Participants & Identity Cues & Construal Level & $\begin{array}{l}\text { Dependent } \\
\text { Variables }\end{array}$ & Results \\
\hline $\begin{array}{l}\text { Study 1: } \\
\text { Recycling } \\
\text { Program }\end{array}$ & $n=80$ & $\begin{array}{l}\text { University } \\
\text { students }\end{array}$ & $\begin{array}{l}\text { New recycling program } \\
\text { recommended by } \\
\text { ingroup (university } \\
\text { friends) or outgroup } \\
\text { (Asian citizens) }\end{array}$ & $\begin{array}{l}\text { Abstract (Why) vs. } \\
\text { Concrete (How) } \\
\text { Mindsets on } \\
\text { recycling }\end{array}$ & Recycling intentions & $\begin{array}{l}\text { Abstract mindset } \\
\text { Ingroup and outgroup cues have a similar impact } \\
\text { on recycling intentions. } \\
\text { Concrete mindset } \\
\text { Ingroup (vs. outgroup) cues have higher recycling } \\
\text { intentions. }\end{array}$ \\
\hline $\begin{array}{l}\text { Study 2: } \\
\text { Sustainable } \\
\text { Shampoo }\end{array}$ & $n=130$ & $\begin{array}{l}\text { Online } \\
\text { experiment } \\
\text { (Amazon } \\
\text { Mturk) }\end{array}$ & $\begin{array}{l}\text { Advertisement about a } \\
\text { newly sustainable } \\
\text { shampoo recommended } \\
\text { by ingroups (U.S. } \\
\text { consumers) or outgroups } \\
\text { (Asian consumers) }\end{array}$ & $\begin{array}{l}\text { Abstract (Why) vs. } \\
\text { Concrete (How) } \\
\text { Mindsets on physical } \\
\text { health }\end{array}$ & $\begin{array}{l}\text { Willingness to pay } \\
\text { for a sustainable } \\
\text { product }\end{array}$ & $\begin{array}{l}\text { Abstract mindset } \\
\text { Ingroup and outgroup cues have a similar impact } \\
\text { on willingness to pay for the sustainable shampoo. } \\
\text { Concrete mindset } \\
\text { Ingroup (vs. outgroup) cues have higher } \\
\text { willingness to pay for the sustainable shampoo. }\end{array}$ \\
\hline $\begin{array}{l}\text { Study 3: } \\
\text { Fair Trade } \\
\text { Product }\end{array}$ & $n=164$ & $\begin{array}{l}\text { University } \\
\text { students }\end{array}$ & $\begin{array}{l}\text { New fair trade product } \\
\text { developed by ingroups } \\
\text { (consumers) or } \\
\text { outgroups (company } \\
\text { designers) }\end{array}$ & $\begin{array}{l}\text { Abstract (Why) vs. } \\
\text { Concrete (How) } \\
\text { Mindsets on } \\
\text { academic success }\end{array}$ & $\begin{array}{l}\text { Buying intentions for } \\
\text { the fair-trade product }\end{array}$ & $\begin{array}{l}\text { Abstract mindset } \\
\text { Ingroup and outgroup cues have a similar impact } \\
\text { on fair trade buying intentions. } \\
\text { Concrete mindset } \\
\text { Ingroup (vs. outgroup) cues have higher fair trade } \\
\text { buying intentions. }\end{array}$ \\
\hline $\begin{array}{l}\text { Study 4: } \\
\text { Women } \\
\text { Empowerment }\end{array}$ & $n=204$ & $\begin{array}{l}\text { Online } \\
\text { experiment } \\
\text { (Amazon } \\
\text { Mturk) }\end{array}$ & $\begin{array}{l}\text { Women Empowerment } \\
\text { Initiative: ingroups } \\
\text { (women) or outgroups } \\
\text { (men). }\end{array}$ & $\begin{array}{l}\text { Abstract (Why) vs. } \\
\text { Concrete (How) } \\
\text { Mindsets on physical } \\
\text { health }\end{array}$ & $\begin{array}{l}\text { Willingness to pay } \\
\text { for the service } \\
\text { Mediation: Social } \\
\text { Goodwill and several } \\
\text { alternative mediators }\end{array}$ & $\begin{array}{l}\text { Abstract mindset } \\
\text { Ingroup and outgroup cues have a similar impact } \\
\text { on willingness to pay for the women empowering } \\
\text { company services. } \\
\text { Concrete mindset } \\
\text { Ingroup (vs. outgroup) cues have higher } \\
\text { willingness to pay for the women empowering } \\
\text { company services. } \\
\text { Social Goodwill mediates the effects in concrete } \\
\text { construal, not in abstract construal. }\end{array}$ \\
\hline
\end{tabular}


Table 3. Participants' Characteristics in the Studies

\begin{tabular}{|c|c|c|c|c|c|c|c|c|c|}
\hline & & \multicolumn{2}{|c|}{$\begin{array}{l}\text { Study } 1 \\
(n=80)\end{array}$} & \multicolumn{2}{|c|}{$\begin{array}{c}\text { Study } 2 \\
(n=130)\end{array}$} & \multicolumn{2}{|c|}{$\begin{array}{l}\text { Study } 3 \\
(n=164)\end{array}$} & \multicolumn{2}{|c|}{$\begin{array}{l}\text { Study } 4 \\
(n=204)\end{array}$} \\
\hline & \multirow{2}{*}{$\begin{array}{l}\text { Study type } \\
\text { Item }\end{array}$} & \multicolumn{2}{|c|}{ University experiment } & \multicolumn{2}{|c|}{ Online experiment } & \multicolumn{2}{|c|}{ University experiment } & \multicolumn{2}{|c|}{ Online experiment } \\
\hline & & Frequency & Percentage & Frequency & Percentage & Frequency & Percentage & Frequency & Percentage \\
\hline \multirow[t]{2}{*}{ Gender } & Female & 50 & 62.5 & 57 & 43.8 & 71 & 43.2 & 103 & 50.5 \\
\hline & Male & 30 & 37.5 & 73 & 56.2 & 93 & 56.8 & 101 & 49.5 \\
\hline Average Age & Mean (SD) & $M=21.3$ & $S D=1.6$ & $M=33.7$ & $S D=11.2$ & $M=25.9$ & $S D=7.3$ & $M=38.8$ & $S D=11.6$ \\
\hline \multirow[t]{8}{*}{ Household income } & Under $\$ 25,000$ & $\mathrm{~N} / \mathrm{A}$ & $\mathrm{N} / \mathrm{A}$ & 32 & 24.6 & N/A & N/A & 32 & 15.7 \\
\hline & $\$ 25,001$ - \$29,999 & N/A & $\mathrm{N} / \mathrm{A}$ & 16 & 12.3 & N/A & N/A & 16 & 7.8 \\
\hline & $\$ 30,000$ - \$34,999 & N/A & N/A & 16 & 12.3 & N/A & N/A & 19 & 9.3 \\
\hline & $\$ 35,000$ - \$39,999 & N/A & N/A & 8 & 6.2 & N/A & N/A & 5 & 2.5 \\
\hline & $\$ 40,000$ - \$49,999 & N/A & N/A & 9 & 6.9 & N/A & N/A & 31 & 15.2 \\
\hline & $\$ 50,000$ - \$59,999 & N/A & N/A & 11 & 8.5 & N/A & N/A & 30 & 14.7 \\
\hline & $\$ 60,000$ - $\$ 84,999$ & N/A & N/A & 18 & 13.8 & N/A & N/A & 35 & 17.2 \\
\hline & Over $\mathbf{\$ 8 5 , 0 0 0}$ & N/A & N/A & 20 & 15.4 & N/A & N/A & 36 & 17.6 \\
\hline \multirow[t]{5}{*}{ Marital status } & Single & 80 & 100.0 & 82 & 63.1 & 131 & 79.9 & 71 & 34.8 \\
\hline & Married & 0 & 0 & 44 & 33.8 & 33 & 20.1 & 121 & 59.3 \\
\hline & Separated / Divorced & 0 & 0 & 2 & 1.5 & 0 & 0 & 10 & 4.9 \\
\hline & Widowed & 0 & 0 & 1 & 0.8 & 0 & 0 & 2 & 1.0 \\
\hline & Missing & 0 & 0 & 1 & 0.8 & 0 & 0 & 0 & 0 \\
\hline
\end{tabular}

Notes: "N/A" represents data not available. Income information is not available due to University research guidelines. 
Running Head: Reducing Ingroup Bias in Ethical Consumption

\section{APPENDICES}

Appendix A. Measurement of Alternative Mediators

\begin{tabular}{|c|c|c|c|}
\hline Name & Items & $\begin{array}{l}\text { Cronbach's } \\
\text { Alpha }\end{array}$ & Source \\
\hline $\begin{array}{l}\text { Human } \\
\text { Presence* }\end{array}$ & $\begin{array}{l}\text { 1. The AT\&T initiative conveys a sense of human contact. } \\
\text { 2. The AT\&T initiative conveys a sense of personalness. } \\
\text { 3. The AT\&T initiative conveys a sense of sociability. } \\
\text { 4. The AT\&T initiative conveys a sense of human warmth. } \\
\text { 5. The AT\&T initiative conveys a sense of human } \\
\text { sensitivity. }\end{array}$ & $\alpha=.934$ & $\begin{array}{l}\text { Gefen \& } \\
\text { Straub, } \\
2004\end{array}$ \\
\hline $\begin{array}{l}\text { Emotional } \\
\text { Attachment** }\end{array}$ & $\begin{array}{l}\text { 1. Affectionate. } \\
\text { 2. Friendly. } \\
\text { 3. Loved. } \\
\text { 4. Peaceful. } \\
\text { 5. Passionate. } \\
\text { 6. Delighted. } \\
\text { 7. Captivated. } \\
\text { 8. Connected. } \\
\text { 9. Bonded. } \\
\text { 10. } \\
\text { Attached. }\end{array}$ & $\alpha=.970$ & $\begin{array}{l}\text { Thomson et } \\
\text { al., } 2005\end{array}$ \\
\hline $\begin{array}{l}\text { Source } \\
\text { Identification } * * *\end{array}$ & $\begin{array}{l}\text { 1. How familiar are you with the AT\&T women } \\
\text { empowerment initiative? } \\
\text { 2. If you have a relationship with the AT\&T empowerment } \\
\text { initiative, how close is the relationship? }\end{array}$ & $\alpha=.908$ & $\begin{array}{l}\text { Thompson } \\
\& \\
\text { Malaviya, } \\
2013\end{array}$ \\
\hline $\begin{array}{l}\text { Brand } \\
\text { Symbolism* }\end{array}$ & $\begin{array}{l}\text { 1. AT\&T adds meaning to people's lives. } \\
\text { 2. AT\&T reflects values that are important to people. } \\
\text { 3. AT\&T connects people with their real selves. } \\
\text { 4. AT\&T connects people with what is really important. }\end{array}$ & $\alpha=.925$ & $\begin{array}{l}\text { Morhart et } \\
\text { al., } 2015\end{array}$ \\
\hline $\begin{array}{l}\text { Altruism } \\
\text { Motives* }\end{array}$ & $\begin{array}{l}\text { 1. AT\&T takes socially beneficial actions because they } \\
\text { believe in the morality of doing so. } \\
\text { 2. AT\&T acts to benefit society for moral reasons. }\end{array}$ & $\alpha=.875$ & $\begin{array}{l}\text { Chernev \& } \\
\text { Blair, } 2015\end{array}$ \\
\hline Selfish Motives* & $\begin{array}{l}\text { 1. AT\&T has selfish reasons for taking social actions. } \\
\text { 2. AT\&T seeks publicity through social actions. }\end{array}$ & $\alpha=.710$ & $\begin{array}{l}\text { Chernev \& } \\
\text { Blair, } 2015\end{array}$ \\
\hline Status* & $\begin{array}{l}\text { 1. The AT\&T initiative is an effort to enhance their image. } \\
\text { 2. The AT\&T initiative is a social status symbol. } \\
\text { 3. The AT\&T initiative is a symbol of success and prestige. }\end{array}$ & $\alpha=.708$ & $\begin{array}{l}\text { O'Cass \& } \\
\text { McEwen, } \\
2004\end{array}$ \\
\hline Sacrifice* & $\begin{array}{l}\text { 1. AT\&T is willing to abandon actions that harm women's } \\
\text { empowerment. } \\
\text { 2. AT\&T is willing to assume responsibilities for helping } \\
\text { empower women. } \\
\text { 3. AT\&T is willing to empower women, without expecting } \\
\text { to be thanked. } \\
\text { 4. Even when it is inconvenient, AT\&T is willing to do } \\
\text { what I think is best for empowering women. } \\
\text { 5. AT\&T is willing to go out of their way to empower } \\
\text { women. }\end{array}$ & $\alpha=.918$ & $\begin{array}{l}\text { Davis et al., } \\
2011\end{array}$ \\
\hline
\end{tabular}


Running Head: Reducing Ingroup Bias in Ethical Consumption

Appendix B. Mediation Analysis in Study 4

Social Goodwill (Chernev \& Blair, 2015)

\begin{tabular}{lllll}
\hline CLT & Effect & BootSE & BootLLCI & BootULCI \\
\hline Concrete & .3410 & .1270 & .1195 & .6172 \\
Abstract & .0358 & .1089 & -.1680 & .2782 \\
\hline
\end{tabular}

Index of moderated mediation

Index BootSE BootLLCI BootULCI

\begin{tabular}{llll}
-.3052 & .1566 & -.6397 & -.0146 \\
\hline
\end{tabular}

Human Presence (Gefen \& Straub, 2004)

\begin{tabular}{lllll}
\hline CLT & Effect & BootSE & BootLLCI & BootULCI \\
\hline Concrete & -.0546 & .0792 & -.2476 & .0681 \\
Abstract & -.0210 & .0665 & -.1731 & .1091 \\
\hline
\end{tabular}

Index of moderated mediation

\begin{tabular}{llll}
\hline Index & BootSE & BootLLCI & BootULCI \\
.0336 & .1008 & -.1561 & .2748 \\
\hline
\end{tabular}

Emotional Attachment (Thomson et al., 2005)

\begin{tabular}{lllll}
\hline CLT & Effect & BootSE & BootLLCI & BootULCI \\
\hline Concrete & -.0016 & .0530 & -.1237 & .1107 \\
Abstract & .0031 & .0590 & -.1265 & .1276 \\
\hline
\end{tabular}

\begin{tabular}{llll}
\hline \multicolumn{4}{l}{ Index of moderated mediation } \\
\hline Index & BootSE & BootLLCI & BootULCI \\
.0048 & .0882 & -.1887 & .1950 \\
\hline
\end{tabular}

Source Identification (Thompson \& Malaviya, 2013)

\begin{tabular}{lllll}
\hline CLT & Effect & BootSE & BootLLCI & BootULCI \\
\hline Concrete & -.0337 & .0661 & -.1909 & .0840 \\
Abstract & .0174 & .0671 & -.1171 & .1710 \\
\hline
\end{tabular}

Index of moderated mediation

\begin{tabular}{llll}
\hline Index & BootSE & BootLLCI & BootULCI \\
.0511 & .0971 & -.1169 & .2868 \\
\hline
\end{tabular}

Brand Symbolism (Morhart et al., 2015)

\begin{tabular}{lllll}
\hline CLT & Effect & BootSE & BootLLCI & BootULCI \\
\hline Concrete & .0035 & .0647 & -.1562 & .1287 \\
Abstract & -.0028 & .0583 & -.1195 & .1355 \\
\hline
\end{tabular}

\section{Index of moderated mediation}


Running Head: Reducing Ingroup Bias in Ethical Consumption

Index BootSE BootLLCI BootULCI

\begin{tabular}{llll}
-.0063 & .1007 & -.1960 & .2496 \\
\hline
\end{tabular}

Altruism Motives (Chernev \& Blair, 2015)

\begin{tabular}{lllll}
\hline CLT & Effect & BootSE & BootLLCI & BootULCI \\
\hline Concrete & -.0026 & .0488 & -.1304 & .0901 \\
Abstract & -.0024 & .0475 & -.1135 & .0962 \\
\hline
\end{tabular}

\begin{tabular}{llll}
\hline \multicolumn{4}{l}{ Index of moderated mediation } \\
\hline Index & BootSE & BootLLCI & BootULCI \\
.0002 & .0650 & -.1300 & .1480 \\
\hline
\end{tabular}

Selfish Motives (Chernev \& Blair, 2015)

\begin{tabular}{|c|c|c|c|c|}
\hline CLT & Effect & BootSE & BootLLCI & BootULCI \\
\hline Concrete & -.0002 & .0356 & -.0809 & .0705 \\
\hline Abstract & -.0257 & .0601 & -.1616 & .0901 \\
\hline \multicolumn{5}{|c|}{ Index of moderated mediation } \\
\hline $\begin{array}{l}\text { Index } \\
-.0255 \\
\end{array}$ & $\begin{array}{l}\text { BootSE } \\
.0678 \\
\end{array}$ & $\begin{array}{l}\text { BootLLCI } \\
-.1816 \\
\end{array}$ & $\begin{array}{l}\text { BootULCI } \\
.1058 \\
\end{array}$ & \\
\hline
\end{tabular}

Company Sacrifice (Davis et al., 2011)

\begin{tabular}{lllll}
\hline CLT & Effect & BootSE & BootLLCI & BootULCI \\
\hline Concrete & -.0308 & .0692 & -.1969 & .0893 \\
Abstract & .0163 & .0564 & -.0918 & .1429 \\
\hline
\end{tabular}

\begin{tabular}{llll}
\hline \multicolumn{4}{l}{ Index of moderated mediation } \\
\hline \multicolumn{1}{l}{} \\
\hline Index & BootSE & BootLLCI & BootULCI \\
.0471 & .0942 & -.1175 & .2695 \\
\hline
\end{tabular}

Status (O'Cass \& McEwen, 2004)

\begin{tabular}{lllll}
\hline CLT & Effect & BootSE & BootLLCI & BootULCI \\
\hline Concrete & .0519 & .0843 & -.1038 & .2383 \\
Abstract & -.0811 & .0841 & -.2678 & .0592 \\
\hline
\end{tabular}

\begin{tabular}{llll}
\hline \multicolumn{4}{l}{ Index of moderated mediation } \\
\hline Index & BootSE & BootLLCI & BootULCI \\
-.1331 & .1246 & -.4299 & .0676 \\
\hline
\end{tabular}

Notes: coding of gender: ( 1 male. 2 female $)$ and CLT ( 0 concrete. 1 abstract $)$. This Appendix presents a summary of moderated-mediation analysis (Hayes, 2013, model 8, $\mathrm{n}=5,000$ ) including all alternative mediators. Consistent with our hypothesis, social goodwill mediates the effects as a standalone item and including all other mediator variables. 
Running Head: Reducing Ingroup Bias in Ethical Consumption

\section{AUTHOR BIOGRAPHIES}

\section{Diego Costa Pinto}

Assistant Professor at NOVA Information Management School (NOVA IMS). Ph.D. in Marketing at Neoma Business School (France). His research focuses on business ethics, sustainable consumption, corporate social responsibility, and social influence, including the European Journal of Marketing, Journal of Consumer Marketing, Journal of Cleaner Production, International Journal of Consumer Studies, Journal of Brand Management, and Journal of Consumer Behaviour.

\section{Adilson Borges}

Professor of Marketing at NEOMA Business School in France. Adilson's research appears in numerous academic outlets including Journal of Consumer Psychology, Marketing Letters, Journal of Business Research, Journal of Retail and Consumer Services, Journal of Advertising, Journal of Consumer Marketing, and the Journal of Retail and Distribution Management. He also serves as an Editorial Review Board Member on the Journal of the Academy of Marketing Science, Journal of Business Research and Journal of Marketing Theory and Practice.

\section{Márcia Maurer Herter}

Assistant Professor of Marketing at Universidade Europeia. Ph.D. in Marketing at Neoma Business School (France). Her research focuses on health behaviors, consumer well-being, and sensorial marketing and has been published in the International Journal of Retail and Distribution Management, Journal of Retailing and Consumer Services, European Journal of Marketing, International Journal of Consumer Studies, and Journal of Cleaner Production. 


\section{Running Head: Reducing Ingroup Bias in Ethical Consumption}

\section{Mário Boto Ferreira}

Mario is a Doctor of Social Psychology and he is an Associate Professor at the University of Lisbon. Mário has published in several top journals in psychology, including Journal of Personality and Social Psychology, Journal of Experimental Psychology, Journal of Experimental Social Psychology, and Journal of Business Research. 